\title{
Özel Eğitim Öğretmenlerinin Özel Gereksinimli Öğrencilere Uygulanan Pedagojik Müzik Terapi Tekniklerine Yönelik Bakış Açıları
}

\author{
DOI: 10.26466/opus.912702 \\ * \\ Burak Sağırkaya* \\ * Dr., Millî Eğitim Bakanlığı, İzmir/Türkiye \\ E-Posta: burak.sagirkaya@gmail.com \\ ORCID: $\underline{0000-0001-5244-957 X}$
}

\section{Öz}

Bu çalışmanın amacı, Özel Ĕ̆itim Bölümü Zihin Engelliler Öğretmenliği Anabilim Dalı mezunu özel eğitim öğretmenlerinin (ÖEÖ) pedagojik müzik terapi (PMT) tekniklerini tanımaları, PMT uygulamalarının özel gereksinimli çocukların eğitim/gelişim alanlarına yönelik etkisini deneyimlemeleri ve mesleki gelişimlerinde bir hareketlilik (mobilization) sürecinin başlatılmasıdır. Araştırmada elde edilen nicel veriler yorumlayıcı paradigmaya dayalı durum betimlemesi modeli ile aktarılmıştır. Araştırma verileri oluşturulan anket formu ile sağlanmış, daha güvenilir sonuçlara ulaşabilmek adına elli $(n=50)$ ÖEÖ'ne yönelik uygulamal özel eğitimde pedagojik müzik terapi semineri (ÖEPMTS) düzenlenmiştir. Elde edilen verilerle ÖEÖ'nin; özel eğitimde (ÖE) müzik terapiye bakış açıları, müzik temelli algıları, müzik temelli yeterlilikleri, sinfflarında müzik temelli uygulamalardan (MTU) yararlanma durumları ve bunları öğrencinin müzik dışı eğitim/gelişim alanlarına yönelik uygulayabilme durumları tespit edilmiştir. ÖEÖ'nin ÖEPMTS sonrası; ÖE'de müziğin müzik dışı pedagojik amaçlara yönelik terapötik etkisini gelişimsel bir boyutta deneyimledikleri, ÖE'e gereksinim duyan öğrencilerin müzik dışı gelişim alanlarına yönelik PMT unsurlarını ÖEÖ tarafindan (pedagojik amaçlar doğrultusunda) kullanılabilirliğinin mümkün olduğu ve mesleki gelişimlerine katkı sağlandı̆̆gl, alan üzerine mesleki motivasyonlarımı arttırıcı eğitim süreçlerine ihtiyaç duydukları sonucuna ulaşılmıştır. Ancak uygulayıcı açısından sinırlı oranda müzik temelli yeterliliğe gereksinim duyan PMT unsurlarının, ÖEÖ tarafindan hangi multidisipliner sınırlar dahilinde kullanılabileceği, bu araştırmada ileri araştırmalara yönelik bir yargı tümcesi olarak tespit edilmiştir.

Anahtar Kelimeler: Müzik terapi, özel eğitimde müzik terapi, pedagojik müzik terapi, özel eğitim. 


\title{
Special Education Teachers' Perspectives on the Use of Pedagogical Music Therapy Techniques for Students with Special Needs
}

\begin{abstract}
This study aims to introduce pedagogical music therapy (PMT) techniques to special education teachers (SETs), who are graduates of the Education of Students with Intellectual Disabilities Program at the Special Education Department. It also aims to help SETs experience the effects of PMT applications on the education and development of children with special needs, as well as to initiate a mobilization process in their professional development. The qualitative data are presented through the case description model within the interpretive paradigm. The data were collected through surveys; and in order to draw more reliable conclusions, a hands-on Seminar on Pedagogical Music Therapy in Special Education (SPMTSE) was organized for SETs working in special education (SE) field. The resulting data were used to determine the perspectives of SETs on the use of music therapy in SE, to explore their states of musical perception and musical competence, and to investigate their uses of music-based practices in $(M B P)$ class, as well as implementation of these for students' education and development in areas other than music. After the SPMTSE, SETs observed the therapeutic effect of music in SE on pedagogical goals other than music, at the developmental level. Besides, it was possible for SETs to use PMT elements with pedagogical aims for the development of SE students in areas other than music, and this contributed to their professional development. Another finding was that SETS need more training to increase their professional motivation in the field.However, the multi-disciplinary boundaries within which SETs might use the PMT elements that require a basic level of musical competence on teacher's part remain an implication for future studies.
\end{abstract}

Keywords: Music therapy, music therapy in special education, pedagogical music therapy, special education. 


\section{Giriş}

Eğitim üzerine yapılan günümüz araştırmalarında, farklı görüş ve önerilerin ortaya konulduğu yaklaşımlara yönelik disiplinler arası bir etkileşimin ön planda olduğu görülmektedir. Sorunun varlığını tespit etmek ve çözme yollarını ortaya koymak için bilimsel araştırmalar, kişisel deneyimler ve deneme-yanılma yolu ile ele alınması gerekmektedir (Karasar, 2007). Eğitim durumlarını ortaya koyan ve yeni yaklaşımlar geliştiren çalışmalar ise bilimsel birikimle, gözlemle ve yapılan analizlerin harmanlanmasıyla mümkün olmaktadır.

Tarih boyunca düşünürler, hekimler fiziksel ve zihinsel gelişimde müziğin önemli bir yeri olduğu savunmuşlardır (Yavuzer, 1999). Bugün müziğin birey üzerindeki fiziksel ve zihinsel etkisi bir savdan ziyade bilimsel dayanak ve ispata dayalı bir zemindedir. Müzik duyarlılığ uyandırma, duygusal algıları arttırma, insanı geliştirme, ruhsal durumun dinginleştirilmesi, güvensizlik ve saldırganlık davranışlarıyla başa çıkmada önemli bir etkendir (Kınalı, 2003). Müzik elementlerinin kullanımı ile özel gereksinimli çocuklarda istendik yönde davranış değişikliği ve sosyalleşme üzerine olumlu sonuçlar alındığı da görülmektedir (Çoban, 2005; Özbey, 2009;Eren, 2014; Pektaş ve Yurga, 2016; McFerran, vd., 2016). Müziğin özel gereksinimli bireylerin fiziksel ve zihinsel gelişimine katkısı olduğu, özgüven artımına dayalı başarı duygusunu aktive ettiği, sözel ve sosyal iletişim becerisine katkı sağladığı yapılan çalışmalarda ortaya konmaktadır (Frick, 1999; Acordino vd., 2006). Bu amaçlar doğrultusunda geliştirilen müzik temelli uygulamaların meydana getirdiği terapötik etkileşimler bireylerin sosyal, duygusal, zihinsel ve fiziksel alanlarına etki etmekte bu etkiler bütünü de müzik terapi biliminin araştırma sahasına girmektedir (Sağırkaya, 2020). Alan yazında müzik terapi biliminin dört ana başlık altında incelendiği görülmektedir. Bunlar medikal süreçler, psikoterapötik süreçler, toplumsal süreçler ve eğitim süreçlerinde müzik terapi olarak sıralanabilir (Toth-Bakos, 2016; s.1645).

Eğitim süreçlerinde müzik terapinin bir kolu ise pedagojik müzik terapidir. PMT gelişim/değişim süreçlerinde MTU'ın kullanımı olarak nitelendirilebilir. Özel gereksinimli bireylerde müziğin etkisi, gelişime ve 
değişime yönelik tamamlayıcı rehabilitatif bir unsur olarak görülmektedir. Zira ÖE'de müzik, bireye göre geliştirilmiş MTU'la çocuğun potansiyelini çıkaracak, kendini ifade edebilmesine olanak sağlayacak, sosyal, davranışsal, bilişsel, psikolojik, duygusal ve motor gelişiminde faydalı olacak bir araç olarak kullanılmalıdır (Rynkiewicz, 2005). ÖE'de müzik elementlerinin kullanımı genel çerçevesi içerisinde, müzik eğitimin amaçlarının örgün eğitim süreçlerinde verilen müzik eğitimi amaçlarından ve bu bağlamda bireyselleştirilmiş MTU'ın ayrımını yapmak gerekmektedir. ÖE sürecinde müzik eğitiminin önemli bir yer teşkil ettiği bu sayede örtük/yancıl kazanımlar elde edildiği bilinmektedir. Fakat müzik dışı alanlara yönelik gelişim/değişim ve rehabilitasyon sürecinden bahsedebilmek için MTU'ın istendik ve bilinçli bir şekilde kullanımı gerekmektedir. Alanyazında tespit edilen ÖE ve müzik temelli etkiye dair sonuçların tamamı müzik terapinin de alanına girmektedir. $\mathrm{O}$ halde; ÖE'de MTU'ın amacı özel eğitim süreçlerinde müzik terapinin amacı ile de örtüşmektedir (Toth-Bakos, 2016). Bu sebeplerden ötürü, PMT terminolojisi her iki unsuru da kapsayıcı bir tanımlama olarak görünmektedir.

MEB, 1997 yılında çıkarılan 573 sayılı K.H.K madde:3 b fıkrasında yapılan tanıma göre "özel eğitim", özel eğitim gerektiren bireylerin eğitim ihtiyaçlarını karşılamak için "özel olarak yetiştirilmiş personel," geliştirilmiş eğitim programları ve yöntemleri ile onların özür ve özelliklerine uygun ortamlarda sürdürülen eğitimi ifade eder. Bu tanımdan yola çıkarak gün geçtikçe karmaşıklaşan eğitim süreçlerinin geleneksel sorun çözme yöntemleri ile işlenmesinin özel eğitime ihtiyaç duyan birey için yetersiz kaldığı söylenebilir. Çünkü ÖE süreçlerinde yetiştirilmiş alan personeline ihtiyaç olduğu kadar eğitimin sürdürülebilir olması için bu personelin mesleki anlamda geliştirilebilir olması da gereklidir. Araştırmalar göstermektedir ki öğretmenlik mesleğinin her alanında olduğu gibi ÖE alanında çalışan öğretmenler karşılaşılan sorunların çözümünde, bilimsel gelişmelerden yeterince yararlanamamaktadırlar (Kara, 2019; Eyüpoğlu, 2019). Bu sonucun ortaya çıkmasında ise karşılaşılan sorunlara alternatif yöntemlerle çözüm üretilmesine yardımcı olacak sahaların öğretmenler tarafından bilinmemesi ve bilgi değişimine direnç gösterilmesi olduğu görüşüdür (West, 2011; Rodriguez, 2017). Bu bulgular müzik temelinde ele alındığında ise öğrenciyi en iyi tanıması beklenen sınıf ve alan öğretmeninin müziği kullanarak öğrenci ile nasıl bir 
etkileşime gireceği, eğitimde tanımlanması gereken bir unsur olarak karşımıza çıkmaktadır. Nitekim ÖE alanında çalışan öğretmenlerin, öğrencilerine dair müzik temelli çağdaş yaklaşımları, onların eğitim sürecine aktarabilmesini kolaylaştıracak destek ve iş birliği ancak bilimsel araştırmalar yolu ile geliştirilebilir. ÖE'de kullanılan her bir yaklaşıma ve tekniğe yönelik uzmanlaşmak bir öğretmenin görevinden çok uzaktır. Fakat bu etkileşimin varlığı ve üzerine temel bilgilere sahip olmanın çalışılan öğrencinin eğitim/gelişim/değişim ve rehabilitasyon sürecine yardımc1 olacağı da bilinmektedir. Bu sebeplerden dolayı ÖE alan öğretmenlerinin müzik temelli yeterliliklerinin tespiti ve sinıflarında müzik temelli etkileşimlerden yararlanmalarını sağlamak büyük önem arz etmektedir. Örneğin alan öğretmeni, öğrencisiyle bir şarkıyı söyleyerek ya da ona eşlik ederek onun nasıl mutlu olduğunu, aralarında nasıl bir iletişimin başladığını, onun nasıl daha uzun bir dikkat süresi geliştirdiğini fark edebilmelidir. Böylelikle bir ÖEÖ'nden özel gereksinimli öğrencisi ile müzikle etkileşim kurabilecek düzeyde müziğin terapötik ve rehabilitatif etkilerini anlamış, birey temelli gelişim değişim sürecinde pedagojik müzik terapinin (PMT) tamamlayıcı yönünü kavramış olması beklenmektedir.

Ne var ki tespit edilen alanyazın araştırma sonuçlarının tamamı; müzik elementlerinin bir araştırmacı, bir müzik eğitimcisi ya da bir müzik terapist tarafın uygulanması sonucu elde edilmiştir. Efektif olarak günün koşulları zihinsel engelli tanısı almış her bireyin bir uzman tarafından bireyselleştirilmiş MTU sürecine dahil edilmesini mümkün kılmamaktadır. $\mathrm{Bu}$ yüzden alan mezunu personelin mesleki yeterliliklerinin desteklenmesi gerektiği düşünülmektedir.

\section{Özel Eğitimde Müzik ve Müzik Terapi}

Birlikte şarkı söylemenin, dans etmenin, ritim tutmanın; bireyin sosyalduygusal gelişimi, özgüveninin artması ve sosyalleşmesinin desteklenmesi açısından olumlu katkısı bulunmaktadır (MEB, 2014). Diğer yandan bir ÖE öğrencisinin müzik temelinde okulda edineceği deneyim akademik değil çoğunlukla sosyal deneyim olmalıdır. ÖE'de MTU'ın kazanımları; başarı, motivasyon, eğlenme, yaratıcı ifade, duygusal tepkilerin deneyimi, streste azalma, sakinleşme, dinleme becerisinde gelişme, işitsel 
algının gelişimi, dikkat süresinin artışı, dil kabiliyetinin gelişimi ve hareket kabiliyetinin artırılması olarak sıralanabilir (MEB, 2014). Yine Millî Eğitim Bakanlığı'nın yayınlamış olduğu özel eğitimde müzik etkinlikleri kitabında konunun önemine dair şu ifadelere yer verildiği görülmüştür.

- Müzik etkinlikleri ile özel eğitime muhtaç çocukların motivasyonu artar.

- Çocuklar ifade ve duygusal tepkilerde deneyim kazanırlar.

- Çocuklar duygularını, düşüncelerini ve yaşadıkları olayları rahatça ifade ederler.

- Çocukların streslerinin azalmasında müzik son derece etkilidir.

- Çocukların öz saygılarının gelişimine yardımcı olur.

- Çocuklar sakinleşir, onlara dinlenme ortamı sağlanır.

- Çocukların benlik değerlerinin artmasına yardımcı olur.

- Çocukların dinleme becerileri, işitsel algıları ve dikkat süreleri artar.

- Dili kullanmalarında yardımcı olur.

- Çocukların dil, motor, bilişsel, öz bakım ve sosyal gelişim alanları desteklenir.

- Müzik ile etkili ve kalıcı öğrenme sağlanır (MEB, 2014).

Öğrenme güçlüğü çeken çocukların, müziğe diğer akranları gibi tepki verdiğini ve müziğin diğer bireylerle iletişim aracı olarak kullanılan bir köprü olduğunu söyleyebiliriz (Perry, 1995). Diğer bir yandan ÖE'e gereksinimi olan çocuklar arasında müziğe duyulan ilginin her hangi bir travmatik bir süreç yaşanmadıkça çok yönlü olumlu etkileri karşımıza çıkmaktadır (Alvin, 1998). Paul Nordoff ve Clive Robbins bu çok yönlülüğü; ritmik eşliğge senkronize olma, odaklanma, dinlerken duygusal tepkiler verme, konuşma faktörleri ve müzikle birlikte hareket etme, iletişim kurma ve sosyalleşmede gelişme olarak sıralamaktadır (Youngshin, 2004).

"Müzik terapisi, müziğin, bireylerin fiziksel, duyusal, toplumsal ve/veya bilişsel gelişimlerine katkıda bulunmak amacıyla kullanılmasıdır. Müzik terapisi sırasında enstrüman çalma, şarkı söyleme, dinleme, müzik parçası oluşturma, müziğe uygun hareketler yapma vb. ögeler yer almaktadır" (AMTA, 2001, aktaran; Alaner, 2002; s.235).

Okulda müzik eğitiminin genel kazanımları müzikal bilgi ve becerileri geliştirmektir (Öner, 2014). Özel gereksinimli bireylerin eğitimde 
kullanılan müzik elementleri ise eğitim süreçlerinde müziğin tamamlayıcı bir etkisi olarak adlandırılabilir ve süreç müzik yoluyla müzikal olmayan kazanımların elde edilmesi olarak görülmelidir. Bu alanda uygulanacak yardımcı unsurlarise şu şekilde sıralanabilir.

- Ritim yapmak,

- Şarkı söylemek,

- Müzik temelli grup çalışmaları yapmak,

- Dinlemeye ve dokunsallığa dayalı reseptif çalışmalar yapmak,

- İmgelem çalışmalar yapmak,

- Dans ve hareket çalışmaları yapmak,

- Aktif dinlemeye dayalı çalışmalar yapmak.

ÖE'de kullanılan müzik terapi süreçlerinde ise bireyin müzik elementlerine yatkınlığını tespit etmek ve bireyin müzik terapiye olan yatkınlığını analitik bir düzlemde ele almak gerekir. Kişiye göre geliştirilmiş müzik temelli yaklaşımlar bir gözlem ve tespit sürecinin sonucunda olmalıdır. Bireyin harekete dayalı biyografisini çıkarmak, müzik temelinde duyuş yeterliliğini tespit etmek, bireyselleştirilmiş MTU geliştirmek ve bu süreçten elde edilecek terapötik etki ancak bilimsel dayanaklar neticesinden mümkündür.

Bu bilgiler ışığında ÖE'de PMT uygulama sürecine dair kazanımların aşağıda yer alan alanlarda daha işlevsel olduğu görülmüştür.

- Kaba ve ince hareket yeteneğinin geliştirilmesi,

- Dikkat sürecinin artırılması,

- Beden farkındalığının geliştirilmesi,

- Sosyal becerilerin geliştirilmesi,

- Sözel ve sözel olmayan iletişimin geliştirilmesi,

- Okul öncesi ve temel eğitim kavramlarının öğreniminin kolaylaştırılması,

- Kendilik kavramının geliştirilmesi,

- Törensel ve tekrarlayıcı davranışların değiştirilmesi ve ortadan kaldırılması,

- Öfke davranışlarının ve dürtüsel hareketliliğin azaltılması,

- Görme, işitme, dokunma gibi duyuların algılanması ve bunların hareket sistemiyle irtibatının sağlanması,

- Anksiyete ve stereotipide regülasyon olarak sıralanabilir (Çoban, 2005). 
Müzik terapinin pedagojik yönünü (PMT) zihinsel yetersizliğe sahip bireylerin yaşam kalitesini yükseltmeye yardımcı olan, özel eğitimde kullanılabilen bir yaklaşım olarak değerlendirilmelidir (Sze ve Yu, 2004; Youngshin, 2004; Stanley, 2020). Müzik terapinin pedagojik yönü (PMT) müziğin müzik dişı pedagojik amaçlar için kullanımı olarak tanımlanabilir (Stanley, 2020). Süreç müzik (eğitimi) elementlerinin terapötik etkisi ile karıştırılmamalı ve ÖE'de yapılan her müzik çalışması (müzik eğitimi) müzik terapi olarak adlandırılmamalıdır. Haz, başarı, fark edilme, koordinasyon, güven ve sakinleşme duyguları müziğin terapötik etkileri arasındadır. Ancak bilimsel kanıta dayalı gözlem, analiz, hedefe dayalı kazanımlar ve bu kazanımlara yönelik birey odaklı MTU geliştirmek terapinin belirleyici unsurlardır. Dil gelişimine yardımcı olacak uygulamalara, motor gelişimi sağlayacak bütüner çalışmalara, uyaran etkisi yüksek seslere yönelik önleyici çalışmalara, bilişsel, kinestetik ve duygu durumsal gelişimi desteleyecek özel alanlarla ilgili çalışmalara yönelik geliştirilmiş MTU özel eğitimde pedagojik müzik terapinin (ÖEPMT) kullanımına yönelik bir kaç örnek olarak verilebilir.

Alanyazın incelendiğinde uzun yıllardır ÖE üzerine yapılan MT araştırmalarının, öğrenme güçlüğüne sahip bireylerin duygusal algı ve duyusal motor becerilerinin geliştirilmesine yönelik; ritmik beceri içeren müzik uygulamaları yolu ile beyin ve davranış ilişkisi üzerinde durulduğu görülmektedir (Atterbury, 1983; Grant ve Lecroy, 1986; Öner, 2014; McFerran, vd., 2016).Öte yandan ÖE'de öğrenme güçlüğüne sahip çocukların motor, iletişimsel, bilişsel, davranışsal ve sosyal/iletişim becerilerinin gelişimini desteklemek için MTU'dan yararlanıldığı görülmektedir. (Alaner, 2002).

$\mathrm{Bu}$ tespitlerden yola çıkarak ÖE'de müziğin terapötik ilişkisinden faydalanacak bir eğitimcinin, bedenin ritmik bir çalgı aleti gibi çalınması ile müzik, hareket ögelerinin birleşmesine yol açacağı ve birden çok duyguyu harekete geçirebileceği söylenebilir ( Bilenvd.,2009) Zira hareket de çocuğun bedensel farkındalığını artırarak davranışlar üzerinde daha etkili bir kontrol sağlanıp, çocuğun eğitsel açıdan daha kolay yönlendirilmesine olanak sağlayacaktır (Özbey, 2009).

Müzik seçimi de PMT süreci için çok önemli bir etkendir. Negatif uyaran etkisi oluşturacak müzikler seçilmemeli ve bireysel müzik-biyografisi çıkartılmalıdır. Yaygın gelişim bozukluğu ve otizm (OSB) üzerine 
çalışmalar yapmış ve Benenzon müzik terapi modelinin mimarı Rolando Omar Benenzon'a göre ise müzik terapisinde, çocuğun o anki ruhsal durumuna uygun müzik parçaları sunulmalıdır (akt: Özbey, 2009). Çocuk bağırma, atma, kırma, kendine ve karşısındakine zarar verme, stereotipik davranış ve sinir krizi durumuna girdiyse bütün müzikal unsurlar susturulmalı ve terapist/uygulayıcı/ögretmen konuşma ve temkinler ile bireyi motive etmeli gerekiyorsa uygulamayı sonlandırabilmelidir (Youngshin, 2004). Şayet çocuk her dürtüsellikte ve tepkisellikte çalışmanın biteceğini koşullarsa, uygulayıcı hiçbir geliştirici çalışma yapamaz. Ancak birey süreç içerisinde kendini iletişime kapatır ise uygulama süreci bitirilmelidir (Youngshin, 2004).

Paul Nordoff ve Clive Robbins kaleme aldıkları ve uygulayıcılara yönelik öneriler sundukları Özel Eğitimde Müzik Terapi ve Engelli Çocuklarda Müzik Terapi adlı kitaplarda ÖE'de PMT unsurları ve MTU'ın kullanımını aşağıda yer alan temeller üzerine kurguladıkları görülmektedir.

- Öncelikle ikili ilişki kurmak için her uygulama duyarlılığı arttırıcı bedensel çalışmalar, bireyler arası etkileşimi arttırıcı ritmik çalışmalarmüzikli oyunlar ile başlamalı ve güven ortamını pekiştirmelidir.

- İkincil olarak peş peşe basitten karmaşı̆̆a müzikal yönergelerle çalışmaya devam etmelidir. Öğrenci birden fazla hareket kombinasyonunu peş peşe iki ya da ikiden fazla gerçekleştirebiliyorsa dikkat seviyesine göre farklı uygulamalara geçilmelidir ya da anlık meydana gelen doğaçlamalar eşliklerle, eko uygulamaları ile sürece devam edilebilir.

- Son aşamada ise öğrencinin hazırbulunuşluk durumuna göre grup çalışmaları ve grup içi faaliyetlere geçilmelidir.

- Uygulama süreci her zaman bir selamlaşma ve bir vedalaşma ile bitirilmeli, bu bir merhaba şarkısı olabileceği gibi bir sembolik ritmik oyun da olabilmelidir.

- Aradaki müzikal bağın başlangıç ve sonucu belirleyici nitelikte olduğu bu çalışmalarda mümkün olduğunca az yönergeyle birlikte başlanıp birlikte bitirmeye ve süreç sonrası bedensel ve zihinsel regülasyona zaman ayrılmalıdır. Öğretmen/uygulayıcı her zaman yardımcı bir başka öğretmeni/uygulayıcı çalışmaya dahil etmelidir 
ki kontrol mekanizması daha işlevsel olabilsin. Çalışmadan elde edilecek kazanımlar ancak birey süreci içselleştirdiği, kabul ettiği ve güven ortamı geliştirildiği sürece elde edilecektir (Nordoff-Robbins, 1983; 2004).

Yapıcı bir müzik terapi sürecinin devam etmesi için öğretmen aile, kurum ve terapistle iş birliği içinde olmalı; gözlem ve analiz notlarının tutulması gerektiğinde bu notların paylaşılması ve yansıtma yoluyla ilerideki sürece nasıl devam edileceğinin istişaresi yapılmalı ve yeni stratejilere açık olunmalıdır.

ÖE'de müzikle terapötik bir etki sağlamak ve çocukla müzikal bir bağ kurabilmek, bilinçli bireylerin elinde çocuğa yeni kapılar açacak, çocuğun dünyasında farklı bir gelişimsel süreç başlatacaktır (Procter, 2018). Ancak öğretmen/uygulayıcı bireyi çok iyi tanımalı çalışma süresinin bireyin içinde bulunduğu duruma göre değişken olabileceğini bilmeli ve bireye göre yaklaşım geliştirme ilkesinden yola çıkarak kendi kazanımları için hangi müzik elementlerini kullanacağına karar verebilmelidir. En önemlisi de MTU sürecinde bireyin müzik elementlerine ve müzik uyaranlarına yatkınlığını (dönüt alınabilirliğini) tespit edebilmelidir.

Bu düşünceden yola çıkarak ÖEÖ tarafından ÖE süreçlerinde uygulanabilirliği mümkün olan ve PMT başlığı altında ele alınabilecek belli başlı MT model ve yaklaşımları şu şekilde sıralanabilir. Orff MT yaklaşımı, Nordoff-Robbins MT modeli, Kreatif MT yaklaşımı.

\section{Orff Müzik Terapi}

Gertrude Orff önderliğinde 1974 yılında Almanya'da başlayan, “Orff-Musiktherapie" hareketi, eğitimde müzik terapinin öncülerinden olmuştur. Konu üzerine "Active Furthering of the Development of the Child" adındaki kitabını 1980 yılında yayınlamıştır. G. Orff'a göre müzik ve ritim beraberinde hareketi getirir. Ritim, hareket bileşkesinde var olan dans müziği tamlayan ana unsurdur. G. Orff müzik terapi çalışması sırasında çocuğun var olan becerilerinin iletişim mekanizmasına katkı sağlanmasını hedeflemiş ve farklı öğrenen bireylerle gerçekleştirdiği müzik terapi seanslarına ağırlık vermiştir. G. Orff bireylerin güven ağ içinde oldukça keyif duygularında artma, buna bağlı olarak gelişim alanlarında farklılaşmalar olduğundan bahseder. Ona göre müzik ve hareket; bireyin 
başka bir bireyle iletişim halinde iken yardımcı materyallerle hareketlendiren, seslerle hayal gücünü geliştiren farkındalığı tetikleyen ve algilama sürecini kuvvetlendiren en güçlü araçtır (Orff, 1980).

G. Orff'un çalışmaları ve Münih Orff Müzik Terapi Merkezi üzerine bir araştırma yapan Christine Plahl, G. Orff'un uygulamalarını ilk olarak iletişim ve hiperaktivite sorunu yaşamakta olan bireylerin eğitiminde kullandığını belirtmiş ve klinik sonuçlar aracılığı ile tekniğin terapötik yönünün birey üzerinde oldukça etkili olduğunu vurgulamıştır (Plahl, 2007). Zira G. Orff'a göre, haz duygusuna bireyin hazırbulunuşluk durumuna göre yaklaşılmalıdır. Çünkü haz beraberinde mutluluk getirir; mutluluksa beraberinde güveni, güven duyan birey ise iletişim kurar, yani iletkendir ve cevap verir (Degryse, 2010). Orff müzik terapiye Orff Schulwerk'in ritmik, hareket, dil, melodi dans yapısını örnek alınarak başlanmış ve tümevarım sürecini gelişim bozuklukları ve öğrenme güçlüğü çeken bireylerde kullanılmasında etkili sonuçlar elde edilmiştir. G. Orff yaklaşımının olumlu sonuçları neticesinde bu terapi sürecinin motor yeti kaybı ve fiziksel iyileştirmeler için de kullanılabilirliğine vurgu yapmıştır (Orff, 1980).

Orff Müzik Terapi gelişimsel problemleri olan çocuklarla kullanılan bir yaklaşım olarak; oyunsallaştırma ve doğaçlama sayesinde bireylerin imgelem dünyalarının gelişimi ve farkındalık seviyelerinin arttırılmasına olanak tanir (Voigt, 2013).

Orff Müzik Terapi uygulama sürecinin aşağıdaki şekilde oluşturulduğu görülmektedir.

- Seslendirme alıştırmaları,

- Şarkı söyleme sıklıkla bedenle eşlik etme,

- Dans ritmik alıştırmalar ve taklit teknikleri,

- Müzikal oyunlar,

- Müzik aleti çalma,

- Müzik dinleme olarak ele alınmaktadır (Voigt, 2013).

Diğer bir deyişle terapi sırasında ritmik müzik, melodik müzik, dans ve hareketsel eğitim araçları kullanarak bireylere yönelik pozitif bir yaklaşım geliştirmenin mümkün olduğu görülmektedir. 


\section{Nordoff-Robbins Müzik Terapi}

Günümüzde yaygın olarak kullanılan "Nordoff-Robbins Müzik Terapi Modeli" (NR-MT) Paul Nordoff ve Clive Robbins tarafindan geliştirilmiş ÖE'de etkisi bilimsel olarak kanıtlanmış ve dünya müzik terapi konfederasyonu tarafından kabul edilen bir modeldir. Bu modele göre müzikle terapi bireyin hareketlilik, iletişim, ikili ve sosyal ilişkilerini düzeltirken kendi olma yolunda yaşam kalitesini arttırır (Nordoff ve Robbins, 1983). Müzik bilgisine ihtiyaç kalmadan birlikte müzik yaparak, şarkı söyleyerek birey kendini gerçekleştirmeye fırsat bulur (Nordoff ve Robbins, 1977). Her şey müzik olabilir ve astolan müzikal olmayanı müziğe nasıl dahil edip birlikte nasıl müzik yapıldığıdır (Nordoff ve Robbins, 2004). Çünkü ikiliye göre müzik; bireyler arası bağı başlatır, iletişimsiz çocuklarda iletişim kurmayı sağlar, yoğunlaşma süresini arttırır, ifade sorunu olanlarda ise kendini ifade sürecini gerçekleştirir.

\section{Kreatif Müzik Terapi}

"Kreatif" müzik terapi 1959-1977 piyanist, besteci Paul Nordoff ve özel eğitimci Clive Robbins tarafından geliştirilen bir müzik terapi modelidir (Öztürk, 2019). Fakat daha sonraları ikilinin çalışmaları ve uygulama teknikleri Nordoff-Robbins müzik terapi modeli olarak anılmış ve kreatif müzik terapi yaklaşımı her ne kadar NR-MT çalışmalarında kullanılsa da bazı müzik terapi ve sanat terapi çevreleri tarafından bağımsız bir model olarak da kullanılmaya başlanmıştır. Kreatif müzik terapi yaklaşımı için referans olarak Paul Nordoff ve Clive Robbins'in 1977 yllında kaleme aldıkları ilk yapıt olan "Creative Music Therapy: Individualized Treatment for the Handicapped Child" adlı kitap gösterilmektedir. Nordoff-Robbins bu kitapta müzik sürecini; -insanlar müziği planlanmış bir eylem olarak düşünürler ama müzik iki kişinin karşılıkl konuşması gibi o an çıkar ve devam eder, çünkü müzik bir başkasıyla bă̆ kurma yoludur, şeklinde ifade etmişlerdir. Kreatif kelimesini dilimize yaratıcı müzik terapi olarak geçirmek doğru olacaktır. Adından da anlaşılacağı üzere belirli bir tekniğe veya modele bağlı kalmadan süreç içerisinde ve belirlenmiş amaçlar için gerçekleştirilen müzik temelli uygulamalar ve süreç içerisinde tamamlayıcı olarak kullanılan ergo ve sanat terapi yaklaşımlarının ortak 
kullanımını kreatif müzik terapi olarak nitelendirmek yanlış olmayacaktir.

ÖE süreçlerinde yaygın olarak kullanılan PMT yaklaşım ve modelleri (Orff Müzik Terapi, Nordoff-Robbins Müzik Terapi ve Kreatif Müzik Terapi) bireylerin nörolojik, bilişsel, duyusal, duygu durumsal, iletişimsel, sosyal ve motor beceri gelişim aşamalarında etkin öğreti süreçleri ortaya koymaktadırlar. Bu düşünceden yola çıkarak çoklu zekâ kuramının müzik ve özel eğitimde müzik terapiye etkisinin ele alındığı Rynkiewicz (2005), şeması aşağıda yer almaktadır.

Tablo 1. Müzik terapinin etki alanlarına genel bakış

\begin{tabular}{|c|c|}
\hline Müzik ve Terapötik Etki & Terapötik Etkiye Örnek \\
\hline Müziğin Duygusal Davranışlarla İlişkisi & $\begin{array}{l}\text { Sakinleşme, gerginleşme, gevşeme, öfke, } \\
\text { üzüntü, }\end{array}$ \\
\hline Müziğin Duyusal Gelişime Etkisi & İmgelem gelişimler, ifade geliştirme, \\
\hline Müziğin Davranışa Etkisi & İstendik davranış geliştirme, farkındalık, \\
\hline Müziğin Hareketle İlişkisi & Kaba ve ince motor kaynaklı hareketlere etki, \\
\hline $\begin{array}{l}\text { Müziğin Nörolojik Değişim/Geliş̧imle } \\
\text { ilişkisi }\end{array}$ & $\begin{array}{l}\text { Müziğin bir hafıza odacı̆̆ oluşturması, olay ve } \\
\text { durum üzerinde bir anı geliştirme, sıralama } \\
\text { bilinci, bilişsel kazanımlar, }\end{array}$ \\
\hline Müziğin Bilinçaltıyla İlisskisi & Yaşanmışlık/bastırılmıslıkların açığa çıkması, \\
\hline Müziğin Beceri Gelisimine Etkisi & Sosval, dinleme, dikkat becerisi, \\
\hline İstendik Hareketle Müziğe Tepki & Dans etme, ritmik hareket, mırıldanmak, \\
\hline Bedenin Müziğe Fizyolojik Tepki Vermesi & Hormonsal reaksiyonlar, \\
\hline $\begin{array}{l}\text { Bedenin Müziğe İstem Dışı Olarak Ha- } \\
\text { reketle Tepki Vermesi }\end{array}$ & Sallanma, irkilme, \\
\hline
\end{tabular}

Yukarıdaki sürecin özel eğitimde müzik terapi ile ilgilenen bir öğretmenin/uygulayıcının terapötik açıdan gerçek anlamda gelişme ve değişme sürecinin hedef ve çıkış noktasını belirlenmesinde yararlı olacağ düşünülmektedir.

\section{Pedagojik Müzik Terapi Normları Üzerinden Özel Gereksinimli Birey- lerin Beceri Alanlarına Yönelik Kazanım Elde Etme Süreçlerinde Öğret- menin Rolü}

"Hemen hemen tüm çocuklarda ulaşllabilecek ve eğitilebilecek bir nokta vardır" (Bilen vd., 2009). Fakat bu noktaları görebilecek ve çocuğa pozitif dokunabilecek özel eğitim öğretmeninin donanımlarının güçlendirilmesi 
gerekmektedir. Bu etkileşimi bireye sağlayacak kaynağın yetersizliği, bireylerin gelişim sürecinde durağanlığa ve gerilemeye neden olabileceği düşünülebilir. Günün koşulları her bir özel eğitim kurumu için alanında uzman olarak yetişmiş bireylerin görev almasını mümkün kılmamaktadır. Amaca uygun eğitim planının gerçekleştirilmesi çoğu zaman özel eğitim öğretmenine düşmektedir. Bireyselleşmiş eğitim programları (BEP) planlama sürecinde öğretmen müziğin rolünü kavrayabilmeli, müziğin davranış kontrolüne etki edebilmesi için etkili stratejiler ve müziğin kullanımına uygun öğretim stratejileri geliştirebilmelidir (Thompson, 1999; Harris, 1991). Özel gereksinimli çocukla çalışan bir eğitimcinin etkili bir sonuç alabilmesi için temel bir müzikal birikime ihtiyaç vardır. Temel süreç basit müzikal kalıplarla da sağlanabilir. Fakat öğretmen uygulama sürecine dahil olan bireyde dönüt verebilir nitelikte bir potansiyel olup olmadığını fark edebilmelidir. Ancak müzik unsurlarıyla bireyin kendi bedenini tanıması, orada da ikili iletişime girmesi için doğaçlama ve ritim duygusunun desteklenmesi öğretmenin de bu sürece dahil olmasıyla da ilintilidir. Çünkü çocukla eğitsel manada en fazla zaman geçiren öğretmen, sosyalleşmeye açılan bir iletişim kapısı niteliğindedir. Müzik bir öğrenme aracıyken gelişim ve iletişim aracı da olabilmektedir (Orff, 1980). Bu bağlamda bir özel eğitim öğretmeni her daim çocuğu geliştirecek yeni yaklaşımlara açık olmalıdır.

Konu üzerine araştırma yapmış uzmanların ortak görüşleri uygulayıcıların ancak sabırla bireye yardım edebileceği ve müzik terapinin çocukların yaşama sevinçlerini arttırılmasında, uyum bozukluklarının davranış problemlerini azaltılmasında ve sosyalleştirilmelerinde etkili olacağ1 yönündedir (Oldfield vd., 2003).

\section{Özel Eğitim Öğretmenlerinin Müzik Temelli Uygulama Sürecinde Karşılaştığı Sorunlar}

Eğitimin niteliğinin geliştirilmesi, teknolojide kaydedilen gelişmeler öğretmenin verimliliğini ve etkisini güçlendirir ancak hiçbir araç gereç ve

yöntem öğretmenin yerini alamaz. Özel eğitim sınıfında pedagojik müzikle terapi unsurları içeren uygulamalar gerçekleştiren bir öğretmen zaman değerlendirme, mekân kullanımı, yönetim, yaklaşım geliştirme ve uygulama sorunlarıyla karşılaşmaktadır (Sağırkaya, 2020). Bu sorunların 
üstesinden gelme ve başarılı bir öğrenme süreci sunma öğretmenin kendi denetimindedir (Thompson, 1999). Öğrenme güçlüğü çeken öğrencinin eğitime dahil olma isteği eğitim sürecini önemli derecede etkilemekte fakat öğrenme yöntemi ve nasıl öğretileceği öğretmenin kendi pratiğine bırakılmaktadır (Öner, 2014). Bu bağlamda pedagojik müzikle terapi unsurları içeren uygulamaları kullanacak bir öğretmen şu sorunlarla karşılaşabilmektedir:

- Öğrenciyi ne kadar tanıyorum?

- Öğrenci MTU sürecine ne kadar hazır?

- Nasıl bir uygulama planı geliştirmeliyim?

- Hedef ve kazanimlarım nelerdir?

- Ne tür çalgılar ve materyaller kullanmalıyım?

- Hangi tür müzik kullanmalıyım?

- Geliştirdiğim MTU hangi gelişim ve değişim alanına yönelik?

- Grup çalışmaları ve gerekiyorsa kaynaştırma evresi ne zaman olmalı?

- Süreci uygulamaya ne kadar istekliyim?

- Bilgilerim ve deneyimim ne boyutta?

$\mathrm{Bu}$ faktörlerin yanında mesleki iş birliği, çalışma ortamı, öğretmenöğrenci, öğretmen-idare, öğretmen-veli faktörleri de devreye girmektedir. Öğretmen mesleki yeterliliklerinin farkında olmalı ve onları geliştirme çabası içerisine girmelidir. Eğitim öğretim sürecinde artan standartların yanında öğretmenlerin yaşam boyu kendilerini eğitim ve uygulama yönünden de geliştirmeleri gerekmektedir (Kış, 2007). Bir özel eğitim öğretmeni uygulayacağı her stratejide öz değerlendirme yapabilmeli ve öğrenci ailesi ve gerekiyorsa diğer alan uzmanları ile iş birliğini devam ettirebilmelidir. Öğretmenin meslektaşlarının deneyimlerinden yararlanabilen, eleştirel düşünceye sahip, iş birlikçi ve güncel olması beklenir (Taşlayan, 2012).

Alanyazın incelendiğinde araştırmalar, öğretmenlerin sınıf içerisinde yeni yaklaşım ve stratejiler geliştirmede mesleki zorluklar yaşadıklarını ortaya koymaktadır (Dedeoğlu vd., 2006; Arslan ve Özpınbar, 2008). Görüldüğü üzere ÖEÖ'nin MTU sürecinde karşılaştığı sorunlar, mesleki anlamda pek çok yönden karşılan sorunlarla örtüşür niteliktedir. O halde öğretmenlerin sahip oldukları kişisel ve mesleki birikimi geliştirmeleri, mevcut gelişmelerle ilgili hizmet içi çalışmalara katılmaları, bir uzman ile 
planlama, program hazırlama, uygulama alanlarında iş birliği içinde olacakları çalışmalar yapmaları da gerekmektedir. Bu da öğretmenlerin çalışma hayatları boyunca da mesleki rehberliğe ihtiyacı olduğunu göstermektedir (MEB, 2020).

Her çocuk bir diğerinden farklıdır ve bu yüzden eğitiminde bireysel temeller olmalıdır (Güven, 2003). ÖE'de bireye göre yaklaşım geliştirme ilkesi her ÖEÖ'nin hakim olması gereken temel ilkelerdendir. Öğretmenlerin de tam bu noktada yeni yaklaşım ve tekniklere doğru kaynaklardan ulaşması gerekir. Çünkü farklı gelişim alanlarına sahip farklı öğrenen çocuklarla çalışan her öğretmen, çocukla arasında bir bağ kuracağı ve onu destekleyeceği yeni yaklaşımlara her zaman ihtiyaç duyacaktır. Ne var ki günümüz koşulları özel eğitim kurumlarında her alan için bir uzmanın bulundurulmasını mümkün kılmamakta bu yüzden ÖE'in her alanında olduğu gibi müziğin gücü de, her ÖEÖ tarafından etkili bir şekilde kullanılması gerekmektedir. Bu savdan yola çıarak bu araştırma ile ÖEÖ'nin PMT'ye bakış açıları ve müzik temelli yeterlilikleri tespit edilip, onlara uygulanan seminer sayesinde mesleki hareketliliğin başlaması hedeflenmiştir.

\section{Problem Durumu}

Yapılan açıklamalar göz önüne alındığında; özel eğitimde pedagojik müzik terapi semineri (ÖEPMTS) süresince PMT alanında kullanılan Orff Müzik Terapi, Nordoff-Robbins Müzik Terapi, Kreatif Müzik Terapi tekniklerinin ve yaklaşımlarına dair kullanım alanları, ÖE'de kullanımı, MTU örnekleri ve öğrenci üzerinde terapötik etkileri ÖEÖ ile paylaşılmıştır. Çünkü eğitimcilerin deneyimlemedikleri bir konuda görüşlerini net olarak elde etmek mümkün görünmemektedir. Onların birinci elden süreci deneyimlemeleri ve kendi mesleki süreçlerine karşın bir farkındalık oluşturulmasının gerekli olduğu görülmüştür. Böylece "Özel eğitim öğretmenlerinin (ÖEÖ) özel eğitimde pedagojik müzik terapiye (ÖEPMT) yönelik düşünceleri ve özel eğitimde pedagojik müzik terapi semineri (ÖEPMTS) sonrası değerlendirmeleri nelerdir?" sorusu bu araştırmanın problemini oluşturmuştur. 


\section{Araştırmanın Amacı}

ÖEÖ'nin ÖE'de kullanılan PMT teknik ve yaklaşımları tanıyarak mesleki gelişimlerine katkı sağlamak ve özel gereksinimli çocukların eğitim/gelişim süreçlerine yönelik MTU'ın terapötik etkisini deneyimlemesini sağlamaktır.

\section{Araştırmanın Önemi}

Bu çalışma; ÖE'de müzik temelli uygulamaların ve kullanılan müzik terapi yaklaşımlarının ÖEÖ tarafından öğrenilmesi ve öğrencinin gelişim sürecinde ÖEÖ tarafından kullanılması açısından önemlidir. ÖE'de öğrenci ile birebir çalışma ilkesi ve yeni teknik ve yaklaşımların ÖEÖ'ne aktarımı ve müziğin terapötik etkisinin öğretmen görüşleriyle ortaya çıkarılması bakımından önemlidir. Özel eğitim kişiye göre yöntem geliştirme ilkesinden yola çıkarak müziğin gelişime katkısının ÖEÖ tarafından gözlemlenmesi açısından önemlidir. Bununla beraber özel eğitim öğretmenlerinin bilinçli müzik uygulamaları yapmaları ve yapılan etkinlikleri test etmek açısından da önemli bir çalışmadır. Araştırmanın yapıldığı sırada, ÖE öğretmenlerine yönelik bu alanla ilgili yapılmış bir çalışma tespit edilememiştir. Bu bağlamda araştırma; ÖEÖ'nin sınıflarında gerçekleştirdiği müzik temelli süreçlerin, bireylerin gelişimi üzerindeki terapötik etkilerine dair işlevselliğin bilinmesi açısından önem taşımaktadır.

\section{Araştırmanın Varsayımları}

$\mathrm{Bu}$ çalışma kapsamında hazırlanan ve kullanılan veri toplama araçlarına verilen yanıtların içten olduğu ve gerçek görüşleri ortaya koyduğu kabul edilmiş olup; araştırma boyunca ÖE'de MTU'ın gelişimsel alanlara yönelik terapötik etkisini elde eden ÖEÖ'nin diğer ÖEÖ'ni de temsil edebileceği, araştırma sonuçlarının farklı engel gruplarına yönelik uygulamaları da kapsadığı varsayılmıştır. 


\section{Araştırmanın Sınırlılıkları}

Bu araştırma, müzik terapi bilim dalının, eğitimde/pedagojik müzik terapi yaklaşımının, özel eğitimde müzik terapi modeli ve eğitimde/pedagojik müzik terapi tekniklerinin (Orff müzik terapi, Nordoff -Robbins müzik terapi, Kreatif müzik terapi) kullanımı ile sinırlıdır.

\section{Yöntem}

$\mathrm{Bu}$ çalışmanın konusunu teşkil eden seminer, Afyonkarahisar ili 35096851-160.99-E7556108 sayılı Valilik onay1 ve 44875058-160.99E.7194151 İl Milli Eğitim Müdürlüğü sayılı onayına istinaden gerçekleştirilmiş olup, katılım gösteren $n=50$ katılımcıdan gönüllü katılımlarına dair onam yazıları alınmıştır.

\section{Araştırmanın Modeli}

$\mathrm{Bu}$ çalışmada veriler durum tespiti amacıyla toplanmıştır. Bulgular yorumlayıcı paradigmaya dayalı durum betimlemesi modeli ile aktarılmıştır.

\section{Veri Toplama Araçları}

Gerçekleştirilen ÖEPMTS katılımcılarına 27 adet üçlü likert tipinde hazırlanmış sorudan oluşan anket formu yöneltilmiştir. Anket formu öğretmenlere yönelik demografik bilgi, konuya dair bilgi durumu, uygulama düzeyi, beceri alanları, bakış açıları ve seminer sonrası seminere dair değerlendirme sorularından oluşmaktadır. Anket verileri ile çalışma gurubunun, özel eğitim alanında uygulanan müzik terapi çalışmaları hakkında görüşlerinin tespit edilmesi amaçlanmıştır.

\section{Veri Toplama Araçlarının Geçerlik ve Güvenirliği}

Alanyazın taramasıyla 100 soruluk bir havuz oluşturulmuş, uzman ve akademisyen görüşlerine dayanarak havuz 50 soruya inidirilmiştir. Oluşturulan bu havuzdan likert tipi tutum envanteri geliştirilmiş ve bu 
envanter özel eğitim ve müzik terapi uzmanlarının görüşlerine sunulmuştur. Uzmanlardan alınan nihai dönütlerle 30 soruluk bir envanter elde edilmiştir. Seminer süreci ve çalışma grubu göz önünde tutularak 30 soru araştırmacının bilgi/birikim süzgecinden de geçirilmiştir. Sonuç itibari ile 27 betimleyici likert tipi soruya ulaşılmıştır. Sorular öğretmen görüşlerinde anlamlı bir bütünlük oluşturması için 4 bölüm olarak aktarılmıştır. Seminerde elde edilen görüşler bilgi/durum tespitine dayalı olarak çözümlenmiş ve betimlenmiştir. Anket geliştirme ve uygulama sürecinde Büyüköztürk vd. (2014, s.125)'nin geliştirdiği anket geliştirme süreci takip edilmiştir.

4 Aşamadan oluşan süreç şu şekildedir.

- Problem tanımlama, amaç ve soruların belirlenmesi,

- Maddelerin yazılması, taslak bir formun oluşturulması,

- Akademisyen görüşlerinin alınması, uzman görüşlerinin alınması,

- Son şekil, incelemelerle ankete son şeklinin verilmesi.

Araştırma sürecinde de alan uzmanı kişilerin görüşlerinden sürekli olarak yararlanılmıştır. Ayrıca özel eğitim alanında kullanılan güncel kaynaklardan veriler toplanarak araştırmacı tarafından karşılaştırma yapılmış ve geçerlilik güvenirlik tespit edilmeye çalışılmıştır.

\section{Verilerin Çözümlenmesi}

Durum tespitine dayalı sorularla öğretmen cevapları betimlenmiştir. Verilerin analizi $n=$ (frekans) ve \% (yüzde) değerleri kullanılarak çözümlenmiş tabloda gösterilmiştir. Buna göre her bir tablo sütununun yüzdelik dilimi $\mathrm{n}=50$ net katılımcı üzerinden $\% 100$ net veri dağılımı olarak gruplandırılmıştır. Çalışma grubundan elde edilen görüşler bilgi/durum tespitine dayalı olarak çözümlenmiş ve betimlenmiştir.

\section{Araştırma Süreci}

\section{ÖEÖ'ne Yönelik ÖEPMTS Seminer İçeriği}

Özel eğitimde uygulamalı müzik terapi semineri sırasında araştırmacı katılımcılara yıllar içerisinde edindiği pedagojik müzik terapi birikimini uygulama örnekleriyle sunmuş/uygulamıştır. 


\section{Seminer Amacı}

- Özel eğitime ihtiyaç duyan farklı gelişen/öğrenen bireylerle çalışanlara Pedagojik/PMT müzik terapi uygulamalarının işlevselliğini tanıtmak/deneyimletmek,

- PMT çalışmalarının birey üzerinde değiştirilmek istenilen davranış, iletişim, hareket ve dikkat becerilerinin kazandırılması/geliştirilmesine olan katkısı üzerine farkındalık sağlamak,

- Katılımcıları yeni yaklaşım ve modellerin kullanımı üzerine cesaretlendirmek,

- Özel eğitimde müzik terapiyi nitelikli bir şekilde yaygınlaştırmak,

- Bu farkındalıklar doğrultusunda özel eğitimde müzik terapinin kullanımına yönelik durum tespitini sağlamak olarak belirlenmiştir.

Müzik terapi uygulamaları katılımcılara aktarılırken; farklı gelişen/öğrenen bireyler ve zihinsel öğrenme/gelişim yetersizliğinden hafif, orta, ağır düzey gruplardan en az birisine dahil olması muhtemel bireylerle çalışan alan öğretmenleri ve uzmanlar göz önünde tutulmuş ve özel eğitimde en yaygın beş gelişim/öğrenim alanı "devinimsel/motor, duygu/durumsal süreç, bilişsel, sosyal/iletişimsel ve davranışsal" üzerinden seminer programı hazırlanmıştır. Katılımcıların özel eğitimde bireye göre yaklaşım geliştirme ilkesinin; gözlem, analiz, uygulama, sonuç ilişkisini direkt ya da dolaylı yoldan bildikleri var sayılarak seminer sürecinde edindikleri deneyimleri kendi çalışma alanlarına uyarlayabilecekleri düşünülmüştür.

Seminerde katılımcılara aşağıdaki seminer hedefler didaktik olarak sunulmuştur:

- Müzik terapi nedir?

- Eğitimde müzik terapi nedir?

- Özel eğitimde kullanılan müzik terapi teknik, yaklaşım ve modelleri nelerdir?

- Neden pedagojik müzik terapi?

- Özel eğitimde müzik terapinin (PMT) etki alanları nelerdir?

Beş hedef konu üzerine iki saat didaktik bir sunum akabinde üç saatlik uygulamalı bir sunumla katılımcılarla; pedagojik müzik terapi model ve 
yaklaşımlarından Orff müzik terapi, Nordoff-Robbins müzik terapi, Kreatif müzik terapiye dair uygulama örnekleri paylaşılmıştır. Pedagojik müzik terapi uygulamaları yine yukarıda bahsi geçen bilgiler doğrultusunda duyusal uyaranların, sosyal uyum davranışlarının ve sıralama örüntülerinin ağırlıklı olduğu bir derecelendirme tekniği ile aktarılmıştır.

Aktarılan uygulama örnekleri şu şekildedir:

- Birinci Derece Uygulamalar (Temel düzey MTU); kişilerin hazırbulunuşluk düzeyi ve kaba motor becerilerindeki işlevselliğe göre zihinsel öğrenme/gelişim yetersizliğinde herhangi bir gruba dahil edilmesi muhtemel bireylerde uygulanabilmektedir.

- IIkinci Derece Uygulamalar (Orta düzey MTU); orta düzey zihinsel gerilik düzeyine sahip bireylere kadar uygulanabilmektedir.

- $\quad$ Üçüncï Derece Uygulamalar (İleri düzey MTU); daha çok hafif düzey zihinsel gerilik düzeyi ve hafif düzey zihinsel retardasyona sahip bireylere kadar uygulanabilmektedir(Rynkiewicz, 2005).

Derecelendirmelere yönelik uygulamalar için eğitim ve öğretim süreçlerinden en az birine dahil olabilen öğrencilere yönelik çalışmalara yer verilmiştir. Bu şekildeki temel çalışmalarla öğretmenlerin müzik terapi uygulamalarını daha akıcı bir şekilde tanımlayacağı ve deneyimleyeceği düşünülmüştür.

$\mathrm{Bu}$ derecelere yönelik pedagojik (eğitimde) müzik terapi uygulama örnekleri şu şekildedir.

Tablo 2. Birinci Derece İçin Hazırlanmış Uygulama Örneği

\begin{tabular}{|c|c|}
\hline \multicolumn{2}{|c|}{ Yansıtma/Aynalama/Eş güdüm odaklı Dans ve Ritim Uygulaması } \\
\hline Uygulama & $\begin{array}{l}\text { Grup çalışmasıdır. Harekete ve yansıtmaya dayalı çalışmalar içerir. Ritmik } \\
\text { devinimin gerçekleşmesi beklenir. }\end{array}$ \\
\hline Yönerge & $\begin{array}{l}\text { Bedenin keşfedilmesine, hareket kabiliyetini fark edilmesine, ritmik uyaran- } \\
\text { ların çalıştırılmasına yönelik yönergeler. }\end{array}$ \\
\hline Kazanımlar & Takip edebilme, sıralama bilinci, dikkat algısı, koordinasyon, konsantrasyon, \\
\hline Uyaran & Tef ya da davul \\
\hline Pekiştirici & Ritmik çalgılar, farklı materyaller ve müzik \\
\hline Gelişim alanı & Devinimsel/motor, bilişsel, sosyal, iletişim, dikkat \\
\hline $\begin{array}{l}\text { Uygulamantn } \\
\text { Yer: Munich } \\
\text { Tarih: Temmı } \\
\text { Konu: Orff M }\end{array}$ & $\begin{array}{l}\text { Referans Terapist: Shirley Salmon } \\
\text { ter, Orff Music Therapy Seminar. Almanya } \\
\text { api }\end{array}$ \\
\hline
\end{tabular}


Tablo 3. Íkinci Derece İçin Hazırlanmış Uygulama Örneği

\begin{tabular}{ll}
\hline Drama, doğaçlama ve işitsel algıya yönelik uygulama \\
\hline Uygulama & $\begin{array}{l}\text { Birçok uyaranın ve yönergenin bulunduğu duyuş ve hissetme ve mo- } \\
\text { tor beceri üzerine çalışmalar içerir. }\end{array}$ \\
\hline Yönerge & $\begin{array}{l}\text { Bedenin uyarılmasına, reflekssel ve anlık uyaranların çalıştırılmasına } \\
\text { yönelik yönergeler. }\end{array}$ \\
\hline Kazanımlar & $\begin{array}{l}\text { Bedenini hissetme, algılama, bağlantı kurabilme, analiz yapabilme ve } \\
\text { analitik düşünme becerisi, }\end{array}$ \\
\hline Uyaran & Tef ya da davul \\
\hline Pekiştirici & Ritmik çalgılar, farklı materyaller ve müzik \\
\hline Gelişim alamı & Devinimsel/ motor, bilişsel, Duygusal \\
\hline $\begin{array}{l}\text { Uygulamanın Alındı̆̆ı Referans Terapist: Simon Procter } \\
\text { Yer: Nordoff-Robbins }\end{array}$ & Music Therapy technique practice Training UK NR Institute Lviv \\
Ukrayna & \\
Tarih: Nisan 2018 & \\
Konu: Nordoff-Robbins Müzik Terapi Teknikleri
\end{tabular}

Tablo 4. Üçüncü Derece İçin Hazırlanmış Uygulama Örneği

\begin{tabular}{ll}
\hline Paralel Hareketlilik Uygulaması \\
\hline Uygulama & $\begin{array}{l}\text { Eşli bir çalışmadır. Kinestetik, bilişsel yönü temel alan müzikli ak- } \\
\text { tiviteler içerir. }\end{array}$ \\
\hline Yönerge & Duygu temelli uyaranların çalıştırılmasına yönelik yönergeler. \\
\hline Kazanımlar & $\begin{array}{l}\text { Mekân algısı, uyum ve sıralama bilinci, dikkat algılama ve bağlantı } \\
\text { kurabilme, }\end{array}$ \\
\hline Uyaran & Tef ya da davul \\
\hline Pekiştirici & Farklı materyaller ve müzik \\
\hline Gelişim alanı & Devinimsel/ motor, bilişsel \\
\hline Uygulamanın Alındığı Referans Terapist: Prof. Ayla Varol Clark \\
Yer: Uluslararası Hisarlı Ahmet Sempozyumu. Kütahya \\
Tarih: Mayıs 2016 \\
Konu: Kreatif Müzik Terapi
\end{tabular}

Tablolarda ÖEPMTS sırasında gerçekleştirilen uygulama örneklerinin süreci, kazanımları, hangi gelişim alanına yönelik uygulanabileceği, uygulamanın referansı, alındığ 1 ğitim veya sempozyum tarihi verilmiştir. Uygulamaların ayrıntıları seminer esnasında kayıt altına alınmış ve arşivlenmiştir.

\section{Uygulayıcının Konu Üzere Uzmanlığının Niteliği}

Araştırmacı 2008 yılından günümüze eğitimde müzik terapi ve özel eğitimde müzik terapi üzerine bir dizi uluslararası sertifika programlarına 
katılmıştır. Bunlar sırası ile: 2009-2010 ve 2011-2012 eğitim öğretim yılları içerisinde: Avrupa Konseyi bursu ile "Specjalny Osrodek SzkolnoWychowawczy" adlı kurumda Dr. Agnieszka Gil-Rynkiewicz ile müzik terapi asistanlık görevi, Bialystok/Polonya. 2010: Chopin Üniversitesi, müzik terapi semineri, Varşova/Polonya. 2011: Munich Orff Merkezi, Orff müzik terapi semineri, Münih/Almanya. 2016: Prof. Gábor Tamás Fejér doğaçlama ve reseptif müzik terapi atölyesi, Pec Güzel Sanatlar Üniversitesi Pec/Macaristan. 2017: Prof. Miroslava Blažeková yaşlılık döneminde müzik terapi, Nitra Müzik Üniversitesi, Nitra/Slovakya. 2018: NordoffRobbins müzik terapi modeli uygulayıcı sertifika programı İngiltere NR Enstitüsü Lviv/Ukrayna. 2018: Sağlık Bakanlığ1 müzik terapi uygulayıc1 sertifika programı İstanbul / Türkiye. 2017-2019: Uluslararası eğitimde müzik terapi ve Orff yaklaşımının müzik terapi süreçlerinde model olarak kullanımı eğitimi (Modül-I kayseri; Modül-II. İzmir; Modül-III. İstanbul) Türkiye. 2018: Eğitimde müzik terapi, DMT/AT/MT; Tateina Chernovus, İzmir/Türkiye.

\section{Çalışma Grubu}

$\mathrm{Bu}$ araştırmada çalışma grubu seminere katılım gösteren $n=50$ özel eğitim alan öğretmeni ve alan uzmanlarından oluşmaktadır.

\section{Çalışma Gruplarının Oluşturulması}

Araştırma sürecinin sağlıklı bir zeminde ilerleyebilmesi için öğretmenlerin seminer sürecine dahil olmalarında, katılımcllık ve sürecin paydaşı olmaya yönelik isteklilik durumu esas alınmıştır. Çalışma grubunun oluşturulmasında araştırmanın amaçları gözetilmiştir. Zira öğretmenlerin edindikleri her bir bilgi ve donanımın mesleki hayatta kendilerini farklı bir boyuta taşıyacağı düşünülmektedir.

\section{Çalışma Grubunun Özellikleri}

Tablo 5. ÖEPMTS'ne özel eğitim (öğretmenliği) bölümü mezunu olduğunu belirten ( $n=25)$, özel eğitim zihinsel engelliler (öğretmenliği) 
bölümü mezunu olduğunu belirten $(\mathrm{n}=18)$, psikolojik danışmanlık ve rehberlik mezunu olduğunu belirten (PDR) $(n=6)$, sosyal hizmetler mezunu olduğunu belirten ( $\mathrm{n}=1)$, 50 kişi katılmıştır.

Tablo 5. Seminere Katılan Bireylerin Çalıştıkları Alanlara Göre Dağılımları (ÖEPMTS)

\begin{tabular}{lll}
\hline Alan & $n$ & $\%$ \\
\hline Özel Eğitim Bölümü & 43 & 86,0 \\
\hline Psikolojik Danışmanlık ve Rehberlik (PDR) & 6 & 12,0 \\
\hline Sosyal Hizmetler & 1 & 2,0 \\
\hline Toplam & 50 & 100,0 \\
\hline
\end{tabular}

Ne var ki zihinsel engelliler (öğretmenliği) bölümünün günümüzde pek çok üniversitenin özel eğitim (öğretmenliği) bölümü içerisinde öğrenci kabul eden bir bölüm olduğu tespit edilmiş olup, veri bütünlüğünün sağlanabilmesi ve terminolojik hatanın önüne geçebilmek adına tablo üzerinde $n=18$ ve $n=25$ 'in toplamı olan $n=43$ oranı verilmiştir. Seminere (yapıldığı tarihte)Afyonkarahisar Merkez ilçede çalışan özel eğitim alanı mezunu öğretmenler arasında \%70 oranında katılımın sağlandığı görülmüştür.

Tablo 6. Seminere Katılan Bireylerin Çalıştıkları Alanlardaki Kıdem Yılları (ÖEPMTS)

\begin{tabular}{cll}
\hline Kıdem Yılı & $n$ & $\%$ \\
\hline $1-5$ & 26 & 52,0 \\
$6-10$ & 12 & 24,0 \\
$11-15$ & 10 & 20,0 \\
15 üstü & 2 & 4,0 \\
Toplam & 50 & 100,0 \\
\hline
\end{tabular}

Tablo 6. ÖEPMTS katılımcılarının \%52 oranında beş yıla kadar mesleki deneyimi olduğunu belirten kişilerden oluştuğunu, on yıla ve on beş yıla kadar mesleki deneyimi olduğunu belirten kişilerin ise eşit orana yakın olduğu ancak 15 yıl üstü özel eğitimde alanında çalışan 2 katılımcı olduğu tespit edilmiştir. 
Tablo 7. Seminere Katılan Bireylerin Demografik Dağılımı (ÖEPMTS)

\begin{tabular}{lll}
\hline Yaş & $\mathbf{n}$ & $\mathbf{\%}$ \\
\hline $20-30$ & 25 & 50,0 \\
$31-40$ & 14 & 28,0 \\
$41-50$ & 10 & 20,0 \\
51 üstü & 1 & 2,0 \\
Toplam & 50 & 100,0 \\
\hline Cinsiyet & $\boldsymbol{n}$ & $\%$ \\
\hline Erkek & 16 & 32,0 \\
Kadın & 34 & 68,0 \\
Toplam & 30 & 100,0 \\
\hline
\end{tabular}

Tablo 7. Seminere katılan bireylerin \%50 oranında 30 yaş altı bireylerden oluştuğu, katılımcıların \%68 oranında kadın bireylerden oluştuğu tespit edilmiştir.

\section{Bulgular}

Tespit edilmek istenen, "ÖEÖ'nin ÖEPMT'ye yönelik düşünceleri ve ÖEPMTS sonrası değerlendirmeleri nelerdir?" sorusuna yönelik bulgular aşağıdaki gibidir:

Tablo 8.ÖEÖ'nin MTU'a Yönelik Bakış Açıları ve Bilgi Birikimlerinin Tespiti

\begin{tabular}{|c|c|c|c|c|c|c|c|c|c|}
\hline & & \multicolumn{2}{|c|}{ Katıliyorum } & \multicolumn{2}{|c|}{ Kismen } & \multicolumn{2}{|c|}{ Katılmiyorum } & \multicolumn{2}{|c|}{ Toplam } \\
\hline & & $\mathrm{f}$ & $\%$ & $\mathrm{f}$ & $\%$ & $\mathrm{f}$ & $\%$ & $\mathrm{f}$ & $\%$ \\
\hline 1 & $\begin{array}{l}\text { Özel eğitim öğretmeni } \\
\text { sınıfında müzik temelli } \\
\text { unsurlarla ilgili yöntemler } \\
\text { kullanabilir. }\end{array}$ & 8 & 16,0 & 17 & 34,0 & 25 & 50,0 & 50 & 100,0 \\
\hline 2 & $\begin{array}{l}\text { Özel eğitim sınıflarında } \\
\text { müzik temelli unsurların } \\
\text { ders sürecine kullanımına } \\
\text { dair deneyimim var. }\end{array}$ & 3 & 6,0 & 4 & 8,0 & 43 & 86,0 & 50 & 100,0 \\
\hline 3 & $\begin{array}{l}\text { Özel eğitim müzik ve } \\
\text { oyun müfredatına göre } \\
\text { lisans veya hizmet içi } \\
\text { düzeyinde eğitim aldım. }\end{array}$ & 5 & 10,0 & 1 & 2,0 & 44 & 88,0 & 50 & 100,0 \\
\hline
\end{tabular}

Tablo 8. Katılımcı grubun ÖEPMTS sonrası fikirlerinin net olarak ortaya konulabilmesi için semir öncesi düşünce profilinin çıkartılması gerekmektedir. Nitekim net bir hedef kitleye sahip, spesifik bir alanda 
yapılan bir çalışmanın, kurgulanabilmesi için ayrıntılı katılımcı profilinin çıkarılması gerekir (Calhoun, 2020; s.20). Buna göre seminer öncesi ÖEÖ'ne yukarıda yer alan üç yargı yöneltilmiştir. Elde edilen bulgular şu şekildedir. Katılımcıların \%58,00'inin ÖEÖ'nin sınıflarında müzik temelli unsurları kullanamayacağı, \%86,00'sının müzik temelli unsurların ders sürecinde kullanımına dair bir deneyimi olmadığ $\% 74,00$ 'ünün özel eğitimde müzik ve oyun müfredatına göre bir eğitim almadığı yönünde dönüt vermiştir.

\section{Tablo 9.ÖEÖ'nin Müzik Terapiye İlişkin Düşüncelerinin Tespiti}

\begin{tabular}{|c|c|c|c|c|c|c|c|c|c|}
\hline \multirow{2}{*}{\multicolumn{2}{|c|}{$\begin{array}{l}\text { Özel Eğitim Öğretmenlerinin } \\
\text { Müzik Terapiye İlişkin Düşün- } \\
\text { celeri }\end{array}$}} & \multicolumn{2}{|c|}{ Katıliyorum } & \multicolumn{2}{|c|}{ Kismen } & \multicolumn{2}{|c|}{ Katılmiyorum } & \multicolumn{2}{|c|}{ Toplam } \\
\hline & & $\mathrm{f}$ & $\%$ & $\mathrm{f}$ & $\%$ & $f$ & $\%$ & $\mathrm{n}$ & $\%$ \\
\hline 4 & $\begin{array}{l}\text { Müzikle terapi, müzik } \\
\text { dersinden farklı bir amaç } \\
\text { doğrultusunda yapılır. } \\
\end{array}$ & 34 & 68,00 & 11 & 22,00 & 5 & 10,00 & 50 & 100,0 \\
\hline 5 & $\begin{array}{l}\text { Müzik bireyin davranış } \\
\text { eğitimine yönelik } \\
\text { geliştirici/eğitici çalışma- } \\
\text { larda kullanılabilir. }\end{array}$ & 43 & 86,00 & 4 & 8,00 & 3 & 6,00 & 50 & 100,0 \\
\hline 6 & $\begin{array}{l}\text { Müzik bireyin al- } \\
\text { gılama/farkındalık düzey- } \\
\text { ine yönelik geliştirici/eğitici } \\
\text { çalışmalarda kullanılabilir. }\end{array}$ & 33 & 66,00 & 15 & 30,00 & 2 & 4,00 & 50 & 100,0 \\
\hline 7 & $\begin{array}{l}\text { Müzik dürtüsel agresif dav- } \\
\text { ranışları söndürmede } \\
\text { kullanılabilir. }\end{array}$ & 17 & 34,00 & 4 & 8,00 & 29 & 58,00 & 50 & 100,0 \\
\hline 8 & $\begin{array}{l}\text { Müzik sakinleştirme ve } \\
\text { anksiyete düzeyini regule } \\
\text { etmekte kullanılabilir. }\end{array}$ & 39 & 78,00 & 9 & 18,00 & 2 & 4,00 & 50 & 100,0 \\
\hline 9 & $\begin{array}{l}\text { Müzik özel gereksinimli bi- } \\
\text { reylerin iletişim ve sosyal } \\
\text { etkileşim kurmasında etki- } \\
\text { lidir. }\end{array}$ & 28 & 56,00 & 15 & 30,00 & 7 & 14,00 & 50 & 100,0 \\
\hline 10 & $\begin{array}{l}\text { Müzik öğrenci ve öğretmen } \\
\text { arasında bir bağ kurarak } \\
\text { güven ortamı sağlar. }\end{array}$ & 37 & 74,00 & 7 & 14,00 & 6 & 12,00 & 50 & 100,0 \\
\hline 11 & $\begin{array}{l}\text { Müziğin özel gereksinimli } \\
\text { bireylerin dikkat ve moti- } \\
\text { vasyon geliştirmesine etkisi } \\
\text { vardır. }\end{array}$ & 46 & 92,00 & 2 & 4,00 & 2 & 4,00 & 50 & 100,0 \\
\hline 12 & $\begin{array}{l}\text { Müzik uygulamalarının } \\
\text { özel eğitime ihtiyaç duyan }\end{array}$ & 46 & 92,00 & 4 & 8,00 & 2 & 4,00 & 50 & 100,0 \\
\hline
\end{tabular}




\begin{tabular}{llllllllll}
\hline & $\begin{array}{l}\text { bireylerin gelişim sürecine } \\
\text { etkisi/katkısı vardır. }\end{array}$ \\
\hline 13 & $\begin{array}{l}\text { Müzik etkili bir olumlu pe- } \\
\text { kiştiricidir. }\end{array}$ & 38 & 76,00 & 9 & 18,00 & 3 & 6,00 & 50 & 100,0 \\
\hline 14 & $\begin{array}{l}\text { Müzik içeren çalışmalar } \\
\text { tüm farklı gelişen/öğrenen } \\
\text { özel eğitim guruplarına uy- } \\
\text { gulanabilir. }\end{array}$ & 41 & 82,00 & 3 & 6,00 & 6 & 12,00 & 50 & 100,0 \\
& & & & & & & & & \\
\hline
\end{tabular}

Tablo 9. Bir ÖEÖ bilinçli olarak yaptığı her müzik temelli uygulamanın çocuk üzerinde terapötik etkisinin olacağını bilmelidir. Bu düşünceden yola çıarak ÖEÖ'nin mesleki gelişim süreçlerinde bilimsel ve pedagojik temellerde müzik terapiye yönelik bakış açılarının ortaya konması önem arz etmektedir. Buna göre seminer sonrası ÖEÖ'ne ÖEPMT'ye yönelik 11 yargı cümlesi yöneltilmiştir. Elde edilen bulgular şu şekildedir. Katılımcıların \%68,00'i müzik terapinin müzik dersinden farklı bir amaç için yapıldığını, \%86,00'sının müziğin davranış eğitimi çalışmalarında kullanılabilir olduğunu, \%66'00'sının algılama ve farkındalık çalışmalarında müziğin etkili olduğunu, \%34,00'ünün müziğin ve müzik uygulamalarının dürtüsel ve agresif davranışları söndürmede kullanılabilir olduğunu, \%78,00'inin sakinleştirme ve anksiyete düzeyini regule etmek için kullanılabilir olduğunu, \%56,00'sının iletişim ve etkileşimde müzikten yararlanılabileceğini, \%74,00'ünün müziğin ikili iletişimde güven ortamina etken olduğunu, \%92,00'sinin müziğin motivasyon ve dikkat süresini arttırdığı ve bireysel gelişim sürecinde kullanılabilir olduğunu, $\% 76,00$ 'sının müziğin pekiştirici olduğunu ve \%82.00'sinin müzik uygulamalarının tüm özel eğitim gruplarında uygulanabilir olduğunu düşündüğü görülmüştür. Katılımclların \%58,00'inin müziğin dürtüsel davranışları söndürmede kullanımının etkili olmayacağı yönünde dönüt verdikleri görülmüştür.

Tablo 10.ÖEÖ’nin Özel Eğitimde Müziğin Birey Üzerindeki Gelişim Alanlarnna Yönelik Uygulama Yeterlilikleri

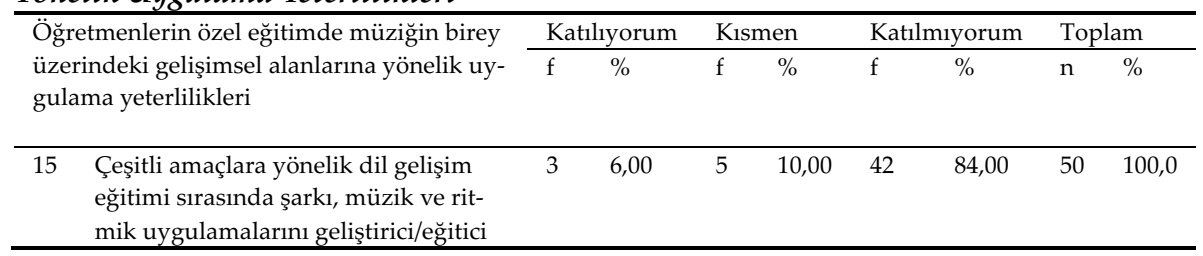




\begin{tabular}{|c|c|c|c|c|c|c|c|c|c|}
\hline & $\begin{array}{l}\text { bir amaç doğrultusunda kullana- } \\
\text { bilirim. }\end{array}$ & & & & & & & & \\
\hline 16 & $\begin{array}{l}\text { Çeşitli amaçlara yönelik hareket/mo- } \\
\text { tor beceri eğitimi sırasında şarkı, } \\
\text { müzik ve ritmik uygulamalarını } \\
\text { geliştirici/eğitici bir amaç doğrul- } \\
\text { tusunda kullanabilirim. }\end{array}$ & 9 & 18,00 & 12 & 24,00 & 29 & 58,00 & 50 & 100,0 \\
\hline 17 & $\begin{array}{l}\text { Çeşitli amaçlara yönelik işitsel algı } \\
\text { eğitimi sırasında şarkı, müzik ve rit- } \\
\text { mik uygulamalarını geliştirici/eğitici } \\
\text { bir amaç doğrultusunda kullana- } \\
\text { bilirim. }\end{array}$ & 7 & 14,00 & 2 & 4,00 & 41 & 82,00 & 50 & 100,0 \\
\hline 18 & $\begin{array}{l}\text { Çeşitli amaçlara yönelik sosyal beceri } \\
\text { kazandırma eğitimi sırasında şarkı, } \\
\text { müzik ve ritmik uygulamalarını } \\
\text { geliştirici/eğitici bir amaç doğrul- } \\
\text { tusunda kullanabilirim. }\end{array}$ & 4 & 8,00 & 9 & 9,00 & 37 & 74,00 & 50 & 100,0 \\
\hline 19 & $\begin{array}{l}\text { Çeşitli amaçlara yönelik ifade/duygu } \\
\text { geliştirme eğitimi sırasında şarkı, } \\
\text { müzik ve ritmik uygulamalarını } \\
\text { geliştirici/eğitici bir amaç doğrul- } \\
\text { tusunda kullanabilirim. }\end{array}$ & 5 & 10,00 & 3 & 6,00 & 42 & 84,00 & 50 & 100,0 \\
\hline 20 & $\begin{array}{l}\text { Çeşitli amaçlara yönelik davranış pe- } \\
\text { kiştirme/geliştirme eğitimin sırasında } \\
\text { şarkı, müzik ve ritmik uygulamalarını } \\
\text { geliştirici/eğitici bir amaç doğrul- } \\
\text { tusunda kullanabilirim. }\end{array}$ & 4 & 8,00 & 8 & 16,00 & 38 & 76,00 & 50 & 100,0 \\
\hline 21 & $\begin{array}{l}\text { Çeşitli amaçlara yönelik dikkat } \\
\text { geliştirme eğitimi sırasında şarkı, } \\
\text { müzik ve ritmik uygulamalarını } \\
\text { geliştirici/eğitici bir amaç doğrul- } \\
\text { tusunda kullanabilirim. }\end{array}$ & 10 & 20,00 & 9 & 18,00 & 31 & 62,00 & 50 & 100,0 \\
\hline 22 & $\begin{array}{l}\text { Çeşitli amaçlara yönelik ders içi/dışı } \\
\text { kullandığım müziği öğrencinin ilgi ve } \\
\text { beğenisine göre seçebilirim. }\end{array}$ & 30 & 60,00 & 14 & 24,00 & 6 & 12,00 & 50 & 100,0 \\
\hline 23 & $\begin{array}{l}\text { Gerektiğinde öğrenciyi motive etmek } \\
\text { ve eğlendirmek için müzikten } \\
\text { yararlanabilirim. }\end{array}$ & 48 & 96,00 & 2 & 4,00 & 0 & 0,00 & 50 & 100,0 \\
\hline
\end{tabular}

Tablo 10. Özel eğitimde gelişim ve değişim süreci iletişim olmadan düşünülemez. Bu düşünceden yola çıarak öğretmenlerinmesleki süreçlerinde müzik temelli yeterlilik ve farkındalık düzeylerinin ve öğrenciye yönelik farklı iletişim kanallarının kullanımının ortaya konulmasın önem arz etmektedir. Buna göre seminer sonrası ÖEÖ'ne uygulama yeterliliklerine yönelik 9 yargı cümlesi yöneltilmiştir. Elde edilen bulgular şu şekildedir. Katılımcıların $\% 84,00$ ünün dil gelişim eğitimi, $\% 58,00$ 'inin hareket/motor beceri eğitimi, \%82,00'sinin işitsel alg1 eğitimi, 
$\% 74,00$ 'ünün sosyal beceri kazandırma eğitimi, \%84,00'ünün davranış pekiştirme/geliştirme eğitimi, \%76,00'sının dikkat geliştirme eğitimi, $\% 62,00$ 'sinin ifade/duygu geliştirme eğitimi sırasında şarkı, müzik ve ritmik uygulamalarını geliştirici/eğitici bir amaç doğrultusunda kullanmadıkları görülmüştür. Katılımcıların çeşitli amaçlara yönelik ders içi/dış1 kullandığ1 müziği öğrencinin ilgi ve beğenisine göre seçme oranının \%60 olduğu ve gerektiğinde öğrenciyi motive etmek ve eğlendirmek için müzikten yararlanabilirim yargısına \%96 oranında dönüt verdiği görülmüştür.

Tablo 11.ÖEÖ'nin ÖEPMTS'ne Yönelik Düşünceleri

\begin{tabular}{|c|c|c|c|c|c|c|c|c|c|}
\hline \multirow{2}{*}{\multicolumn{2}{|c|}{$\begin{array}{l}\text { Öğretmenlerin Seminere yönelik } \\
\text { düşünceleri }\end{array}$}} & \multicolumn{2}{|c|}{ Katıliyorum } & \multicolumn{2}{|c|}{ Kismen } & \multicolumn{2}{|c|}{ Katılmiyorum } & \multicolumn{2}{|c|}{ Toplam } \\
\hline & & $\mathrm{f}$ & $\%$ & $\mathrm{f}$ & $\%$ & $\mathrm{f}$ & $\%$ & $\mathrm{n}$ & $\%$ \\
\hline 24 & $\begin{array}{l}\text { Özel eğitimde pedagojik } \\
\text { müzik terapi semineri } \\
\text { faydalı bir amaca hizmet } \\
\text { etmiştir. }\end{array}$ & 37 & 74,0 & 13 & 26,0 & 0 & 0,0 & 50 & 100,0 \\
\hline 25 & $\begin{array}{l}\text { Özel eğitimde pedagojik } \\
\text { müzik terapi seminerinde } \\
\text { gösterilen uygulamaların } \\
\text { özel eğitimde kullanımı } \\
\text { faydalıdır. }\end{array}$ & 31 & 62,0 & 12 & 24,0 & 7 & 14,0 & 50 & 100,0 \\
\hline 26 & $\begin{array}{l}\text { Seminerle alan üzerindeki } \\
\text { farkındalığım artmıştır. }\end{array}$ & 39 & 78,0 & 9 & 18,0 & 2 & 4,0 & 50 & 100,0 \\
\hline 27 & $\begin{array}{l}\text { Özel eğitimde kullanılan } \\
\text { pedagojik müzik terapi uy- } \\
\text { gulamaları hakkında bilgim } \\
\text { artmıştır. }\end{array}$ & 41 & 82,0 & 9 & 18,0 & 0 & 0,0 & 50 & 100,0 \\
\hline
\end{tabular}

Tablo 11. Bir ÖEÖ çağın getirisi olarak mesleki donanımını sürekli tazelemeli ve çocuğa dokunabilmek için yeni yaklaşım ve teknikleri nasıl kullanabileceğini bilmelidir. Bu düşünceden yola çıkarak ÖEÖ'nin mesleki süreçlerinde çağdaş yaklaşımları deneyimleyebilecekleri ve mesleki potansiyellerine yeni bir boyut katacağı düşünülen ÖEPMTS'ne yönelik düşüncelerinin ortaya konulması önem arz etmektedir. Buna göre seminer sonrası ÖEÖ'nin düşüncelerinin tespitine dair 4 yarg1 cümlesi yöneltilmiştir. Elde edilen bulgular şu şekildedir. Katılımcıların \%74,00'ünün özel eğitimde pedagojik müzik terapi seminerini faydalı bulduğu, \%62,00'sinin seminerde gösterilen uygulamaların özel eğitimde 
kullanılabilir buldukları, \%78,00'inin özel eğitimde müzik terapi üzerine farkındalık geliştirdikleri, \%82,00'sinin özel eğitimde kullanılan müzik terapi teknikleri hakkında bilgi sahibi oldukları görülmüştür.

\section{Tartışma ve Sonuç}

Katılımcıların ÖEPMTS ile birlikte müzik terapiye bakış açıları, bilgi birikimi, öğretmen nezdinde özel eğitim öğrencisinde gerçekleşmesi muhtemel terapötik etkinin; davranışsal, eğitsel ve gelişimsel etkilerinin farkındalığına yönelik durum tespiti yapılmıştır. Böylelikle seminere katılan öğretmenlerin büyük bölümünde müzik terapinin özel eğitimde kullanımına dair olumlu farkındalık ve bilgi düzeyine ulaşıldığ görülmüştür. Nitekim Li (2016), tarafından gerçekleştirilen "The Efeectiveness of Music Therapy for Children with Autism Spectrum Disorder: A Meta-analysis" meta analizi müzik terapinin OSB üzerindeki etkisini 11 farklı araştırmanın analiziyle gözler önüne sermektedir. Meta analizi sonuçlarına göre; müziğin terapötik etkisi bireylerin sosyal yetenekleri, nörolojik gelişimi, davranış gelişimi, bilişsel gelişimi, duyusal gelişimi ve sözlü ve sözsüz iletişim yetenekleri üzerinde etkisi tespit edilmiştir. Bu bağlamda öğretmenlerin ÖE'de müziğin terapötik işlevselliğini direk ve dolaylı yoldan fark etmeleri, Li (2016)'nin meta analiz sonuçlarıyla örtüşür nitelik taşıdığı düşünülmektedir.

Bulgularda öğretmenlerin alanlarını ilgilendiren diğer yenilikçi yaklaşım ve uygulama tekniklerine olumlu baktıkları fakat mesleki gelişim süreçlerinde motive edici destek çalışmalarından yeteri kadar yararlanamadıkları tespit edilmiştir. Konu ile ilgili olarak, Wong ve Chik (2016), müzik öğretmenlerinin kaynaştırma sınıflarındaki özel gereksinimli öğrencilerle ilişkileri, tecrübeleri ve sorunları üzerine yaptıkları araştırmada, müzik öğretmenlerinin özel gereksinimli öğrencilerin müzikal ihtiyaçlarına ve gelişim süreçlerini nasıl destekleyeceklerine ilişkin deneyim sahibi olmadıkları ve motivasyon düşüklüğü yaşadıkları sonucuna ulaşmışlardır. Turan (2006), ise araştırmasında öğretmenlerin müzik dersine yönelik yeterliliklerinin düşük olduğu sonucuna ulaşan bulgular ortaya koymuştur. Araştırmanın bulguları Wong ve Chik (2016), Turan (2006)'nın savlarıyla örtüşür niteliktedir. Ancak sonuçlar 
hedeflenen çalışma grubunun uzmanlığı ve hedeflenen çalışma alanı bağlamında farklılık gösterdiği düşünülmektedir.

\section{ÖEPMTS sonrası mesleki potansiyelleri ve düşünceleri ortaya konulan} katılımcı dönütlerinden elde edilen bulgulara göre;

- ÖEÖ'nin büyük oranda derslerinde müzik elementlerinden yararlanmak istedikleri fakat ÖE'de müzik elementlerini ve MTU'1 derslerinde nasıl kullanabilecekleri üzerine bilgileri olmadığı sonucuna ulaşılmıştır.

- ÖEÖ'nin müziğin ÖE'de farklı amaçlar için kullanılabilir olduğunu, müziğin bireylerin sosyal ve iletişim ihtiyaçlarını karşılayabilir olduğunu ve müziğin farklı gelişim alanlarına yönelik kullanılabilir olduğunu düşündükleri sonucuna ulaşılmıştır.

- ÖEÖ'nin ÖE müfredatına göre sınıflarında gelişim alanlarına yönelik kazanımlar, BEP üzerinde çalışmalar ve farklı pedagojik amaçlara yönelik yapılan kazanım uygulamaları gerçekleştirirken öğrenci potansiyellerini analiz edebildikleri ve onların hazır bulunuşluk düzeylerine göre müziği bir uyaran ya da pekiştireç olarak kullanabilecekleri sonucuna ulaşılmıştır.

- ÖEPMTS sonrasında katılımcıların öğrenci ile müzikal bağın nasıl kurulup gelişimsel ve değişimsel sürecin müzikle nasıl işleneceğini deneyimledikleri sonucuna ulaşılmıştır.

- ÖEÖ'nin müzik dışı kazanımlara yönelik şarkı, müzik ve ritmik uygulamalarını geliştirici/eğitici bir amaç doğrultusunda kullanabileceklerinin farkına vardıkları sonucuna ulaşılmıştır.

- ÖE süreçlerinde müzik terapinin entegresine ilişkin ÖEÖ tarafından pozitif bir tutum geliştirildiği sonucuna ulaşılmıştır.

- PMT unsuru olan ÖEMT çalışmalarının ÖE'e gereksinim duyan farklı öğrenen bireylerin eğitiminde alan ÖEÖ'i inisiyatifinde kullanabilirliğinin mümkün olduğu görüşünün benimsendiği sonucuna ulaşılmıştır.

- MT'in ÖE'in her seviyesinde kullanılabilir olduğu görüşünün benimsendiği sonucuna ulaşılmıştır.

- MTU'ın öğretmen tarafından birey üzerindeki gelişimsel alanlara yönelik geliştirici/eğitici bir amaç doğrultusunda kullanımının mümkün olduğu görüşünün benimsendiği sonucuna ulaşılmıştır. 
- MTU'ın iletişim eğitiminde ve sosyalleşme çalışmalarında işlevsel bulunduğu görüşünün benimsendiği sonucuna ulaşılmıştır.

- MTU'ın olumlu istendik davranış geliştirilmesine yardımcı olacağı görüşünün benimsendiği sonucuna ulaşılmıştır.

- MT'in ÖE'i destekleyici terapi yöntemlerinden biri olarak kullanılabilirliği görüşünün benimsendiği sonucuna ulaşılmıştır.

- ÖEÖ'nin müzikal ilgiyi ve beğeniyi analiz edebildikleri ve öğrencinin hazırbulunuşluk düzeylerine göre müziği bir uyaran ya da pekiştirici olarak kullanabildikleri sonucuna ulaşılmıştır.

- ÖEPMTS'i sayesinde ÖEÖ'nin müziğin ÖE'de gelişimsel ve değişimsel alanlarda terapötik etkisini deneyimledikleri ve bu alan üzerine bir bilgi birikimine sahip oldukları sonucuna ulaşılmıştır.

- ÖEÖ'nin büyük bir bölümünün müzik içeren uygulamaların hangi kazanım alanlarına yönelik etkili olabileceğini ve birey için geliştirdikleri hedef/kazanımlarda MTU'a yer vermedikleri sonucuna ulaşılmıştır.

- Katılımcı ÖEÖ'nin müziğin terapötik etkisinin özel eğitim süreçlerine pozitif katkılarını fark ettikleri fakat sürece dair temel bir eğitim almak konusunda istekli olmadıkları sonucuna ulaşılmıştır.

\section{Öneriler}

- Araştırmada elde edilen sonuçlar ışığında alan öğretmenlerinin öğrencilerinin müzikal potansiyellerini tanımlayabildikleri, onların beğenilerinin farkında oldukları ve müzik temelli iletişim kurabilecek düzeyde temel birikime sahip oldukları, fakat sahip olduğu müzikal alg1 potansiyelinin zaman içerisinde doğru şekilde yönlenmediği ve bu algının tekrardan doğru şekilde kazandırılmasının gerekliliği yargısına ulaşılmıştır. Bu yargı neticesinde alana yönelik aşağıda yer alan öneriler şu şekilde sıralanabilir.

- ÖE'de müzik eğitiminin ve müzik dışı amaçlar için müzik temelli uygulamaların ortak ve farklarının ortaya konulup, müzik terapi temelinde kullanımlarına dair araştırmaların yapılması;

- ÖE alanda çalışan eğitimci ve uygulayıcılara yönelik müzik elementlerinin BEP hazırlama süreçlerine dair hizmet içi eğitimlerin düzenlenmesi; 
- Pedagojik müzik terapi unsuru olan özel eğitimde müzik terapi teknik, yaklaşım ve uygulamalarının müfredatın işleniş şemasına göre sınıflandırılarak eğitimde kullanımına dair araştırmaların yapılması önerilebilir.

- $\mathrm{Bu}$ araştırmada ulaşılan bulgura yönelik alanyazın araştırmalarına ulaşılamamış olup; betimlenen sonuçların, ÖE alanında çalışan ÖEÖ'nin PMT yaklaşımının ÖEMT modeline dair bilgi ve birikime sahip olmalarına yönelik önem arz ettiği düşünülmektedir. Buna ek olarak araştırmada ulaşılan sonuçlarının, ÖEÖ'nin PMT unsurlarını ÖE süreçlerine dahil edebilmesi ve bu süreçte öğretmen rolünün belirlenmesi adına yapılacak ileri araştırmalara önemli katkılar sağlayabileceği düşünülmektedir. 


\title{
EXTENDED ABSTRACT
}

\section{Special EducationTeachers' Perspectives on the Use of Pedagogical Music Therapy Techniques for Students with Special Needs}

\author{
Burak Sağırkaya \\ Ministry of National Education
}

This study aims to introduce pedagogical music therapy techniques to special education teachers through music therapy based seminar. Also aim to help them experience the effects of pedagogical music therapy applications on the education and development of children with special needs and to investigate special education teachers professional development process. This quantitative research study based on a Interpretive Paradigm. The research process, findings, and results are presented through a case description model. Data collection instruments for this study were interview forms, seminar program and reflection meeting.

Seminar on pedagogical music therapy in special educationwas organized for special education teachers working in special education. Seminar based on literature and expert reviews. Seminar consists of two parts. First part (didactic): Aimed to give knowledge about music therapy and music therapy in education (Pedagogical music therapy) on different aspects to special education teachers. Second part (practice): Aimed to give practice a about basic knowledge of pedagogical music therapy techniques to special education teachers. During seminar three Pedagogical music therapy models were adopted in the way that teachers can understand more easily. Those are Orff music therapy, Nordoff-Robbins music therapy and Creative music therapy models. The resulting data were used to determine the perspectives of special education teachers on the use of music therapy in special education. Seminar on pedagogical music therapy in special education played a vital role in contacting the special education teachers who need to their states of musical perception, musical competence, and their uses of music-based practices in class. In the light of the teacher competencies, the researcher reached the implementation, evaluation, analysis, and reflection data on pedagogical music therapy 
techniques in special education by special education teacher. The seminar program was revised throughout the process to address participant teachers' needs.

Before starting the research, the following three question were asked. What problems do special education teachers face during music based practices? Can special education teachers benefit from pedagogical music therapy applications in special education?How much special education teachers believe in the power of the music therapy and music based applications?

The aim of the research was to contribute to the professional development of special education teachers by recognizing pedagogical music therapy approaches used in education. To ensure that children with special needs experience the therapeutic effect of music therapy for their education / development processes. In this study, data were collected $n=50$ special education teachers who are attended the seminar for due diligence. Findings are conveyed with an interpretive paradigm-based situation description model as a Method of the research.In this study data collection tools consist of a questionnaire and questionnaire form consisting of 27 triple Likert type questions. These questions were directed to the pedagogical music therapy seminar participants from field of the special education.

Research findings regarding the application competencies of special education teachers for the development areas of music on the individual in special education reached. Findings regarding the determination of special education teachers' thoughts on music therapy were obtained. Findings regarding the determination of the perspectives and knowledge of special education teachers towards music-based applications reached. Findings regarding the opinions of special education teachers towards pedagogical music therapy seminars in special education reached.

As research conclusions with this study, special education teachers working in the field of special education; It was concluded that the pedagogical Music Therapy approach, knowledge and experience of the music therapy model in special education are important for the field and that seminars are necessary for the service to be done in this field. 
Researching the use of music lessons given in special education undergraduate departments for music therapy in special education and organized trainings, seminars, courses for special education teachers can be presented as recommendation of this study.

At the end of the seminar, conclusions about the teachers' perspectives on the program were reached.Those conclusions are; seminar contributed how the pedagogic music therapy outcomes of the teachers developed music-based practices and also teachers practiced the implementation of the areas other than music with music practices.

During the seminar, special education teacher were seen to observe the therapeutic effect of music in special education on pedagogical goals other than music, at a developmental level. The process showed that this research contributed significantly to the special education teacher professional development and special education teacher could develop musicbased implementation for special education students, directed at developmental areas other than music; and it is possible for special education teacher to use pedagogical music therapy for pedagogical goals in special education. However, the inter-disciplinary and multi-disciplinary boundaries within which special education teacher might use the pedagogical music therapy elements that necessitate basic knowledge of music remain an implication for future studies.

\section{Kaynakça / References}

Accordino, R., Comer, R. ve Heller B.W. (2006). A critical review of music therapy with autistic individuals. Music and Research,1, 101-115.

Alaner, A. B. (2002). Yaratıcı (creative) müzik terapisi yöntemleri ve Eskişehir Anadolu Üniversitesi'ndeki uygulama.21.yy. Başında Türkiye'de Müzik Sempozyumu, SCA Müzik Vakfi-Gazi Üniversitesi, Ankara, 235-245.

Alvin, J. (1998). Music for the handicapped children. (2. Baskı). London: Oxford University Press.

Arslan, S. ve Özpınar, İ. (2008). Öğretmen nitelikleri: İlköğretim programlarının beklentileri ve eğitim fakültelerinin kazandırdıkları. Necatibey Eğitim Fakültesi Elektronik Fen ve Matematik Eğitimi Dergisi (EFMED), 2(1), 38-63. 
Atterbury, B. V. (1983). A comparison of rhythm pattern perception and performance in normal and learning-disabled readers, age seven and eight. Journal of Research in Music Education, 31, 259-270.

Bilen, S. Özevir, B. ve Canakay, E. (2009). Orff destekli etkinliklerle müzik eğitimi. Ankara: Müzik Eğitim Yayınları.

Büyüköztürk, Ş. Çakmak, E.B. Akgün, Ö. E. Karadeniz, Ş. Demirel, F. (2014). Bilimsel araştırma yöntemleri. 18. Basım, Pegem akademik yayınları, Ankara

Çoban, A. (2005). Müzik terapi. (1. Bask1), İstanbul: Timaş Yayınları.

Dedeoğlu, S. Durali, S. ve Kış, A. (2006). Özel eğitim bölümü zihinsel engelliler öğretmenliği ana bilim dalı 3., 4. sınıf öğrenci ve mezunlarının kendi bölüm programları, öğretmen yetiştirme ve eğitim fakülteleri ile ilgili düşünce ve görüşleri. Ankara Üniversitesi Eğitim Bilimleri Fakültesi Özel Eğitim Dergisi, 1, 44-55.

Degryse, M. (2010). Creating a safe place in the midst of aggression: Music therapy in child psychiatry. Approaches: Music Therapy\& Special Music Education, 2(2), 48-54.

Eren, B. (2014). Use of music in special education and application examples from Turkey. Procedia-social and behavioral sciences, 116, 2593-2597.

Eyüpoğlu, G. (2019). Özel eğitim kurumlarında görev yapan müziköğretmenlerinin bu kurumlardaki müzik eğitimine ve öğrencilere yönelik tutumlarmın incelenmesi. Yüksek Lisans Tezi, Karadeniz Üniversitesi Eğitim Bilimleri Enstitüsü, Trabzon.

Frick, J. W. (1999). A qualitative study of music and communication in a musically richearly childhood special education classroom. Unpublished Doctoral Dissertation, George Mason University, Virginia.

Grant, R. E. And Lecroy, S. (1986). Effects of sensory mode input on the performance of rhythmic perception tasks by mentally retarded subjects. Journal of Music Therapy,23(1), 2-9.

Güven, Y. (2003). Özel eğitime giriş, farklı gelişen çocuklar. A. Kulaksızoğlu, (Ed.), İstanbul: Epilson Yayınları.

Harris, T. P. (1991). The development teaching strategies for the multiplehandicapped music classroom. Doctoral Dissertation, Kentucky: University of Louisville, School of Music, Louisville.

Kara, S. (2019). Özel eğitim öğretmenlerinin özel eğitim süreçlerinde müzik eğitimi entegrasyonuna ilişkin görüşlerinin incelenmesi. Yüksek Lisans Tezi, Necmettin Erbakan Üniversitesi, Eğitim Bilimleri Enstitüsü, Konya. 
Karasar, N. (2007). Bilimsel araştırma yöntemi. (17. Basım), Ankara: Nobel Yayın Dağıtım.

Kınalı, G. (2003). Zihin engellilerde beden-resim-müzik eğitimi, farklı gelişen çocuklar. A. Kulaksızoğlu (Ed.), İstanbul: Epilson Yayınları.

Li, M. (2016). The effectiveness of music therapy for children with autism spectrum disorder: A meta-analysis. USA: Arizona State University.

McFerran, K. S., Thompson, G., ve Bolger, L. (2016). The impact of fostering relationships through music with in a special school classroom for students with autism spectrum disorder: an action research study. Educational Action Research, 24(2), 241-259.

MEB, (2014). Çocuk gelişimi ve eğitimi, özel eğitimde müzik etkinlikleri. Millî Eğitim Bakanlığı Özel Eğitim ve Rehberlik Hizmetleri Genel Müdürlüğ̈u, Ankara.

MEB, (2020). Özel eğitim uygulama okulu müzik dersi öğretim programı. Millî Eğitim Bakanlığı Özel Eğitim ve Rehberlik Hizmetleri Genel Müdürlüğ̈̈, Ankara.

Nordoff, P., Robbins, C. (1977). Creative music therapy: Individualized treatment for the handicapped child. John Day Co: First Printing Ed. Michigan Üniversitesi, ABD.

Nordoff, P., Robbins, C. (1983). Music therapy in special education. (2nd Edition), By Paperback, USA: Barcelona Publishers.

Nordoff, P., Robbins, C. (2004). Therapy in music for handicapped children. USA: Barcelona Publishers.

Orff, G. (1980). Orff music therapy active furthering of the development of the child. Tel-Aviv: Mnb. Music Publishing.

Oldfield, A., Adams, M., \&Bunce, L. (2003). An investigation into short-term music therapy with mothers and young children. British Journal of Music Therapy, 17(1), 26-45.

Öner, A.K. (2014). Açık anlatım yönteminin hafif düzeyde öğrenme güçlüğ̈̈̈ne sahip öğrencilerin müzik dersindeki ritmik beceri eğitimine etkisinin analizi. Doktora Tezi, Necmettin Erbakan Üniversitesi, Eğitim Bilimleri Enstitüsü, Güzel Sanatlar Eğitimi Anabilim Dalı, Müzik Eğitimi Bilim Dalı, Konya.

Özbey, Ç. (2009). Özel çocuklar ve terapi yöntemleri. (1. Baskı). İstanbul: İnkilap Yayınları.

Öztürk, L. (2019). Müzik terapi terimler sözlüğ̈̈ Ankara: Hipokrat Kitap Evi Yayınları. 
Pektaş, S., ve Yurga, C. (2016). Özel eğitimde oyun ve müzik etkinlikleri. Turkish Journal of Arts and Social Sciences, 2(2), 33-38.

Perry, T. M. (1995). Music lessons for children with special needs. London: Jessic Kingsley Publishers.

Plahl, C. (2007). Micro analysis of preverbal communication in music therapy. London: Jessica Kingsley Press.

Procter, S. (2018, 15 Nisan). "Nordoff-Robbins müzik terapi eğitimi" ( Dr. Simon Procter ile Yüz Yüze Görüşme). Lviv, Ukrayna.

Rodriguez, D. (2017). Music integration therapy: An instructional tool for students with special needs. Doktora Tezi, Capella University, Minnesota.

Rynkiewicz. A, (2005). Zastosowanie muzykoterapii u osób z zaburzeniami ze spektrum autyzmu. (TR:Otizm spektrum bozukluğunda müzik terapinin kullanımı),Centrum Diagnozy, Warszawa: Terapii i Edukacji, $3(1), 11-26$.

Sağırkaya, B. (2020). Özel eğitim öğretmenlerinin pedagojik müzik terapi tekniklerini uygulama durumları. Doktora Tezi, Necmettin Erbakan Üniversitesi, Eğitim Bilimleri Enstitüsü, Konya.

Stanley, L. (2020, 7 Ekim). "Müzik Terapinin Pedagojik Yönün, Music Therapy's Pedagogical Aspects" (Webinar), Yeni Zelanda.

Sze, S. and Yu, S. (2004). Effects of music therapy on children with disabilities. Proceedings of the 8th International Conference on Music Perception\&Cognition ICMPC8, USA: Evanston, 341-343.

Taşlayan, S. M. (2012). Nitelikli bir öğretmende bulunması gereken özelliklerin öğretmen adayları görüşlerine göre incelenmesi. Mersin Üniversitesi Sosyal Bilimler Enstitüsü Dergisi, 33(2), 213-298.

Thompson, K. R. (1999). Challenges of inclusion for the general music teacher. General Music Today, 12(7), 7-9.

Toth-Bakos, A. (2016). Music education and music therapy. 10th International Technology, Education and Development Conference, Valencia, Spain. P.: 1643-1652.

Turan, D. (2006). Özel eğitimde müzikten yararlanmada karşılaşılan sorunlarla ilgili öğretmen görüşlerinin incelenmesi. Yüksek Lisans Tezi, Marmara Üniversitesi Eğitim Bilimleri Enstitüsü, İstanbul.

Voight, M. (2013). Orff music therapy: History, principles and further development. Approaches: Music therapy and special music education. Special Issue: 5(2), 97-105. 
West, C. (2011). Action research as a professional development activity. Arts Education Policy Review, 112(2), 89-94.

Wong, M. W. Y. ve Chik, M. P. Y. (2016). Teaching students with special educational needs in inclusive music classrooms: experiences of music teachers in Hong Kong primary schools. National Music Education Research, 18(2), 195-207.

Yavuzer, H. (1999). Çocuk psikolojisi. İstanbul: Remzi Kitapevi.

Youngshin, K. (2004). The early beginnings of Nordoff-Robbins music therapy. Pubmed, J Music Ther, 41(4), 321-339.PMID: 15762836

\section{Kaynakça Bilgisi / Citation Information}

Sağırkaya, B. (2021). Özel eğitim öğretmenlerinin özel gereksinimli öğrencilere uygulanan pedagojik müzik terapi tekniklerine yönelik bakış açıları. OPUS-Uluslararası Toplum Araştırmaları Dergisi, 18(39), 308-347. DOI: 10.26466/opus.912702. 